\title{
Lomonosovfonna and Holtedahlfonna ice cores reveal east-west disparities of the Spitsbergen environment since AD 1700
}

\author{
Emilie BEAUDON, ${ }^{1}$ John C. MOORE, ${ }^{1,2,3}$ Tõnu MARTMA, ${ }^{4}$ Veijo A. POHJOLA, ${ }^{3}$ \\ Roderik S.W. VAN DE WAL, ${ }^{5}$ Jack KOHLER, ${ }^{6}$ Elisabeth ISAKSSON ${ }^{6}$ \\ ${ }^{1}$ Arctic Centre, University of Lapland, Rovaniemi, Finland \\ E-mail: emilie.beaudon@ulapland.fi \\ ${ }^{2}$ Colleges of Global Change and Earth System Science, Beijing Normal University, Beijing, China \\ ${ }^{3}$ Department of Earth Sciences, Uppsala University, Uppsala, Sweden \\ ${ }^{4}$ Institute of Geology, Tallinn University of Technology, Tallinn, Estonia \\ ${ }^{5}$ Institute for Marine and Atmospheric Research Utrecht, Utrecht University, Utrecht, The Netherlands \\ ${ }^{6}$ Norwegian Polar Institute, Fram Centre, Tromsø, Norway
}

\begin{abstract}
An ice core extracted from Holtedahlfonna ice cap, western Spitsbergen, record spanning the period 1700-2005, was analyzed for major ions. The leading empirical orthogonal function (EOF) component is correlated with an index of summer melt $\left(\log \left(\left[\mathrm{Na}^{+}\right] /\left[\mathrm{Mg}^{2+}\right]\right)\right.$ from 1850 and shows that almost $50 \%$ of the variance can be attributed to seasonal melting since the beginning of the industrial revolution. The Holtedahlfonna $\delta^{18} \mathrm{O}$ value is less negative than in the more easterly Lomonosovfonna ice core, suggesting that moist air masses originate from a closer source, most likely the Greenland Sea. During the Little Ice Age the lower methanesulfonic acid (MSA) concentration and MSA non-sea-salt sulfate fraction are consistent with the Greenland Sea as the main source for biogenic ions in the ice cores. Both the melt index and the MSA fraction suggest that the early decades of the 18th century may have exhibited the coldest summers of the last $\mathbf{3 0 0}$ years in Svalbard. Ammonium concentrations rise from 1880, which may result from the warming of the Greenland Sea or from zonal differences in atmospheric pollution transport over Svalbard. During winter, neutralized aerosols are trapped within the tropospheric inversion layer, which is usually weaker over open seas than over sea ice, placing Holtedahlfonna within the inversion more frequently than Lomonosovfonna.
\end{abstract}

\section{INTRODUCTION}

Sea-ice cover is an important modulator of the decadal-scale climate variability in the Arctic. The largest temperature changes associated with the high winter sea-ice cover variability are observed in the Greenland-Barents-Kara seas (Bengtsson and others, 2004), which receive warm water driven by the southwesterly to westerly winds between Svalbard and the northernmost Norwegian coast. The location of Svalbard, at the southern edge of the permanent sea-ice cover of the Arctic Ocean and on the pathway of both Arctic and North Atlantic cyclones, contributes to the relatively mild climate compared with most of the Arctic. Sea-ice variations have been one of the main driving forces of the Svalbard climate over at least the past 500 years (Isaksson and others, 2005a; Grinsted and others, 2006), hence Svalbard is an interesting location to conduct climate studies in the European Arctic Ocean sector.

Previous Svalbard ice cores have proven the suitability of these records for paleoclimate investigations despite alteration by post-depositional processes, in particular seasonal melt (Pohjola and others, 2002a; Kekonen and others, 2005; Van der Wel and others, 2011). Consequently, a panel of proxies and statistical tools, useful in deciphering climatic signals disrupted by melting, has been developed for these low-altitude ice caps. For instance, lizuka and others (2002) and Grinsted and others (2006) found good summer melting indices based on ion concentrations of snow and ice from Austfonna, Nordaustlandet, and Lomonosovfonna, eastern Spitsbergen (Fig. 1). Moore and others (2005) examined the impact of seasonal melt using principal components analysis (PCA) on the complete
Lomonosovfonna ion dataset. Environmental signals were separated from melting in Lomonosovfonna (Kekonen and others, 2005), Austfonna (Watanabe and others, 2001) and Vestfonna (Nordaustlandet) (Matoba and others, 2002) ice cores with detection of Medieval Warm Period (Kekonen and others, 2005) and Little Ice Age (LIA) at multi-year or multi-decadal resolution (Watanabe and others, 2001; Matoba and others, 2002). The origins of major chemical species were discussed (Kekonen and others, 2002) and a regional-scale picture of the anthropogenic pollution history has been composed, the 20th-century sulfate sources in particular being inventoried by Moore and others (2006) for Lomonosovfonna ice cap.

North-south disparities across Svalbard due to the influence of the Arctic front and the impact of the ice extent of the Barents Sea were identified by comparing the Austfonna ice core with Lomonosovfonna (Isaksson and others, 2005b). However, glaciochemical references for western Spitsbergen are lacking, with the exception of the Snøfjellafonna ice core drilled in 1995 with a published record spanning only 70 years (Kameda and others, 1993; GotoAzuma and others, 1995; Goto-Azuma and Koerner, 2001). The new chemical dataset from a long ice core drilled on Holtedahlfonna presented here aims to fill this gap and provides the first century-length paleo-environmental equivalent to the Lomonosovfonna core for western Spitsbergen. Although these two ice caps lie at the same altitude and only $100 \mathrm{~km}$ apart on the same island, the complex and diverse Svalbard environment leads to somewhat dissimilar ice-core signatures. In this paper we compare the chemical dataset from these two glaciers throughout their overlapping 


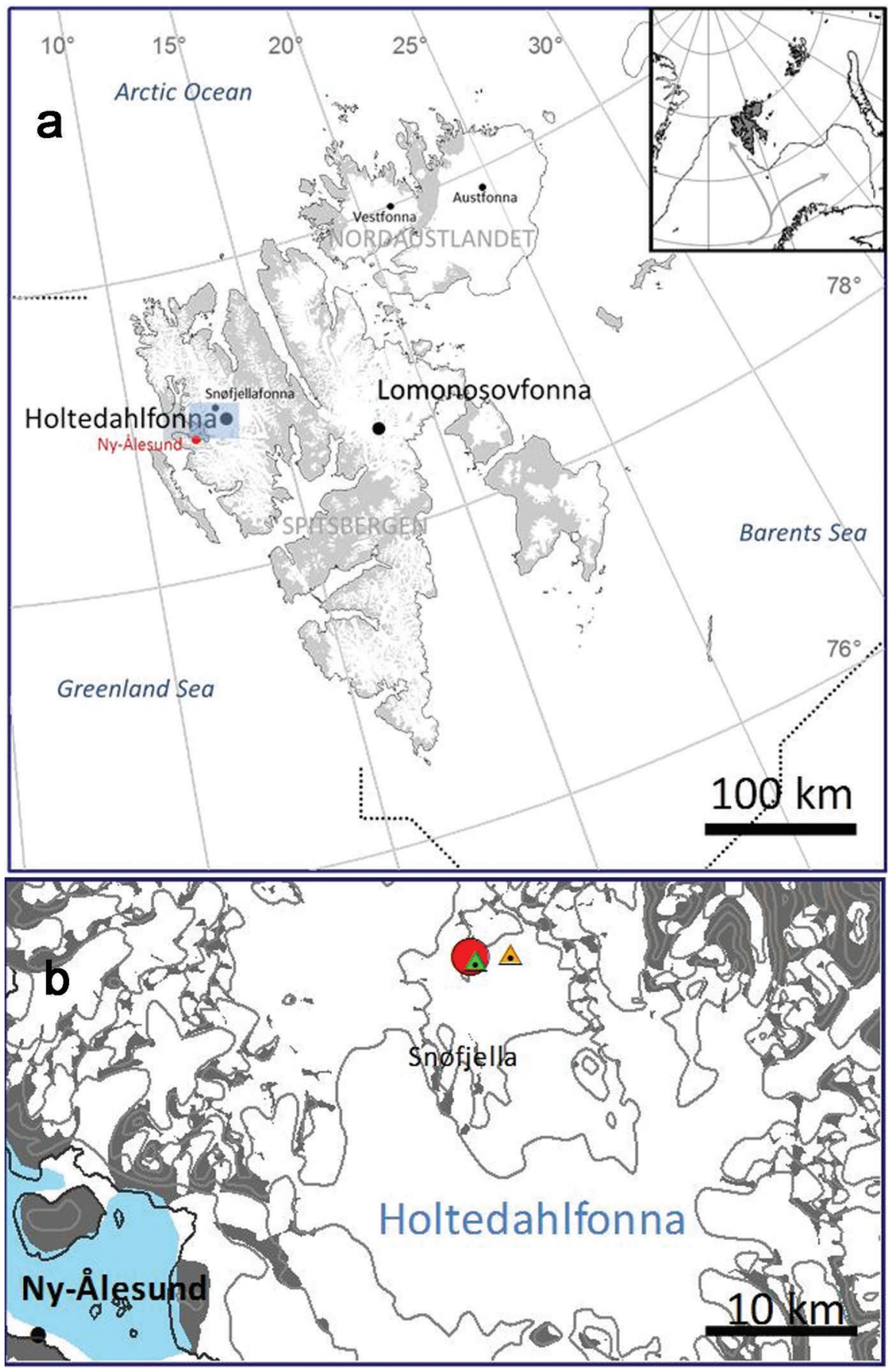

Fig. 1. (a) Map of Svalbard showing Holtedahlfonna ice-core site and Lomonosovfonna ice cap. The dotted line segments represent the median spring sea-ice extent over the period 1979-2000 (source: http://nsidc.org/data/seaice_index/archives/index.html). (b) Holtedahlfonna with the location of the drilling sites for the long 2005 core (red circle), the Snøfjellafonna core (Goto-Azuma and others, 1995; green triangle) and the firn core 2008 (orange triangle).

time period and, using statistical methods, we discuss the differences in their respective ionic budget focusing on biogenic sulfur and ammonium.

\section{SITE DESCRIPTION AND DATING}

\subsection{Glaciological characteristics}

Holtedahlfonna ice field is the largest ice field $\left(300 \mathrm{~km}^{2}\right)$ in northwestern Spitsbergen island, Svalbard, Norway, $40 \mathrm{~km}$ from the Ny-Ålesund and Zeppelinfjellet stations and $100 \mathrm{~km}$ northwest of Lomonosovfonna ice cap (1255 ma.s.l.) (Fig. 1). In April 2005 a $125 \mathrm{~m}$ long ice core was drilled using an electromechanical corer on Holtedahlfonna $\left(79^{\circ} 8^{\prime} 15^{\prime} \mathrm{N}, 13^{\circ} 16^{\prime} 20^{\prime} \mathrm{E} ; 1150 \mathrm{~m}\right.$ a.s.l.) from a saddle point where the horizontal ice-flow velocity is expected to be minimal (Lefauconnier and others, 1994; Sjögren and others, 2007). The ice core did not reach bedrock. Ice depths around the core site were obtained by radar sounding using a pulse radar with a center frequency of $10 \mathrm{MHz}$. The basal topography at the core site is extremely rugged (Fig. 2a), with radarderived ice depths varying from about 100 to $250 \mathrm{~m}$ for data within $50 \mathrm{~m}$ of the core site (Fig. 2b). The imprecisely known depth complicates the dating of the ice core (see Section 2.3). The bottom temperature in the borehole was $-3.3^{\circ} \mathrm{C}$, hence the whole core is cold ice (Fig. 3a). Ice temperature measured in the borehole features a maximum of $-0.4^{\circ} \mathrm{C}$ at $15 \mathrm{~m}$ depth 

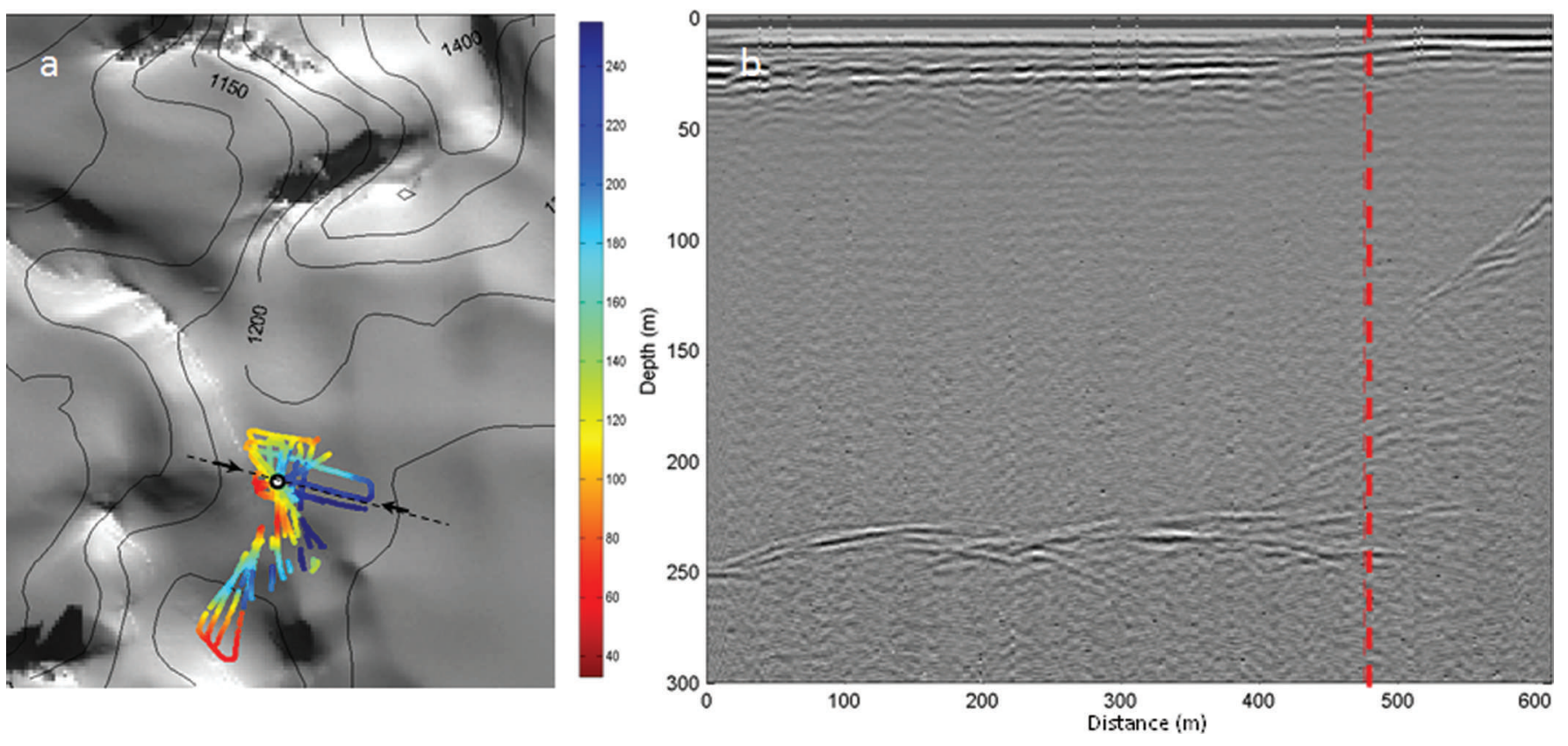

Fig. 2. (a) Topographical map of the drilling site (black circle) area showing radar survey tracks. The black arrows and the dashed black line show the track corresponding to the radargram shown in (b). (b) Radar profile passing over the drilling site (dashed red line).

(Sommer, 2005). Latent heat from refreezing of percolating meltwater is assumed to produce the thermal maximum at $15 \mathrm{~m}$ and is expected to impact chemistry, as discussed in Section 3.2.

\subsection{Sampling and analysis}

On average, $60 \mathrm{~cm}$ long ice-core pieces were retrieved and packed in clean plastic bags, placed in insulated boxes and transported under frozen conditions to the Norwegian Polar Institute, Tromsø, Norway, where dielectric profiling (DEP) and high-resolution density measurements were performed along the entire core (Sjögren and others, 2007) before subsampling for chemical measurements.

In a cold room, parallel-sided sections of the core were cut and distributed for tritium (Van der Wel and others, 2011), oxygen isotope (Divine and others, 2011), organic contaminant (Ruggirello and others, 2010) and ion measurements (this study) for which rectangular sections were collected from the inner part of the core. At the Finnish Forest Institute (Rovaniemi research station) the core pieces as well as blanks made from ultrapure Milli-Q water were subsampled into $10-20 \mathrm{~cm}$ long increments. A total of 740 samples were melted at room temperature in a clean room just before being analyzed for major water-soluble ions $\left(\mathrm{Na}^{+}, \mathrm{NH}_{4}{ }^{+}, \mathrm{K}^{+}, \mathrm{Mg}^{2+}\right.$, $\left.\mathrm{Ca}^{2+}, \mathrm{CH}_{3} \mathrm{SO}_{3}{ }^{-}, \mathrm{Cl}^{-}, \mathrm{SO}_{4}{ }^{2-}, \mathrm{NO}_{3}{ }^{-}\right)$via Dionex ion-suppressed chromatography (DX-120 series) equipped with Dionex lonpack CS12 columns for the cation channel and with Dionex lonpack AS15 columns for the anion channel. Kekonen and others (2002, 2004) and Virkkunen (2004) describe the analytical methods in detail. Mean blank values (12 samples) obtained were $0.09 \pm 0.8 \mathrm{ngg}^{-1}$ for sodium, $0.8 \pm 1.5 \mathrm{ng} \mathrm{g}^{-1}$ for ammonium, $0.2 \pm 0.1 \mathrm{ngg}^{-1}$ for potassium, $0.08 \pm 0.09 \mathrm{ng} \mathrm{g}^{-1}$ for magnesium, $0.5 \pm 0.7 \mathrm{ng} \mathrm{g}^{-1}$ for calcium, $0.03 \pm 009 \mathrm{ng} \mathrm{g}^{-1}$ for methanesulfonic acid (MSA), $1.01 \pm 0.7 \mathrm{ng} \mathrm{g}^{-1}$ for chloride, $0.9 \pm 0.6 \mathrm{ng} \mathrm{g}^{-1}$ for sulfate and $0.2 \pm 0.9 \mathrm{ng} \mathrm{g}^{-1}$ for nitrate. Non-sea-salt (nss) fractions of calcium, sulfate, magnesium and chloride were calculated using a conservative sea-salt species, i.e. sodium, as the seasalt indicator (Keene and others, 1986).

\subsection{Dating}

Previous studies using the Holtedahlfonna ice-core data (Sjögren and others, 2007; Ruggirello and others, 2010; Van der Wel and others, 2011) used an age-depth scale based on

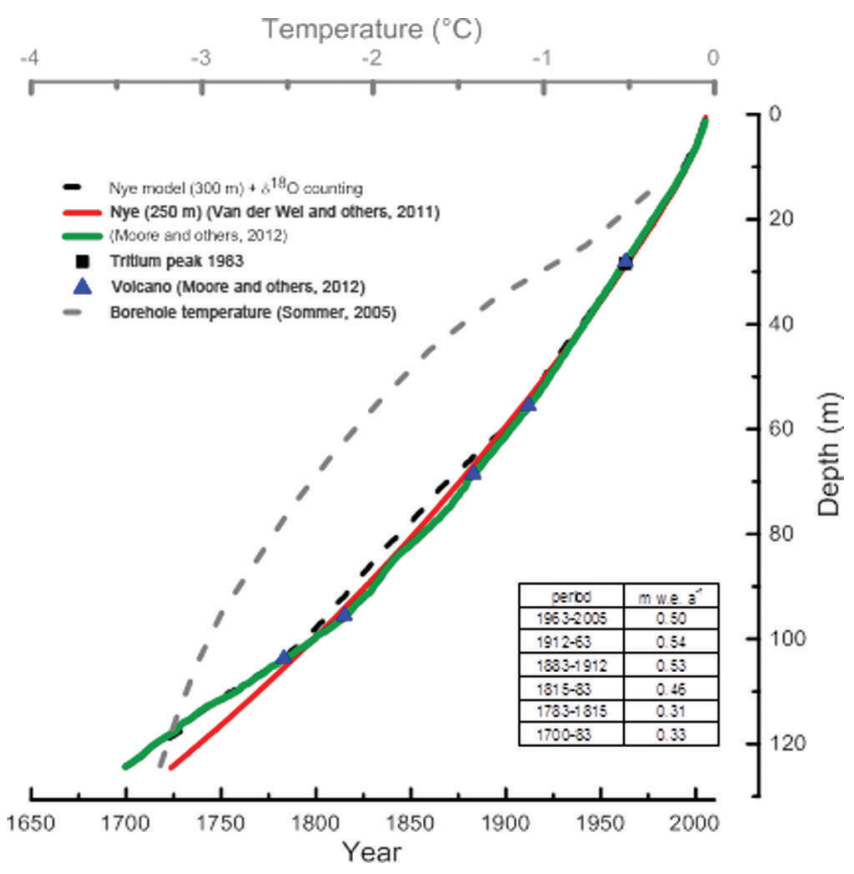

Fig. 3. Temperature profile (gray dashed curve) measured along the borehole (Sommer, 2005). Age-depth scale combining the Nye age scale assuming a glacier thickness of $300 \mathrm{~m}$ with an automated $\delta^{18} \mathrm{O}$ cycle counting (black dashed curve). Nye age scale (for a glacier thickness of $250 \mathrm{~m}$ ) used in Van der Wel and others (2011) (red curve). Age scale developed by Moore and others (2012) (green curve) using five volcanic reference horizons (blue triangles) with cycle counting and employed in this study. The table (inset) shows the average accumulation rates calculated for intervals between volcanic reference horizons and decompressed using a Nye model with $300 \mathrm{~m}$ ice depth. 
the Nye thinning model (Nye, 1963) constrained by the depth of the 1963 radioactivity fallout layer at $28.5 \mathrm{~m}$ depth (Van der Wel and others, 2011), giving a constant accumulation rate $\left(0.50 \mathrm{~m}\right.$ w.e. $\mathrm{a}^{-1}$ for $\left.1963-2005\right)$ together with a range of plausible ice thicknesses (Fig. 3b). Divine and others (2011) used automated counting of annual $\delta^{18} \mathrm{O}$ (Pohjola and others, 2002b) layers to derive variable accumulation rates. The rate of thinning of layers is best matched with the Nye age-depth model having a glacier thickness of $300 \mathrm{~m}$, which is $150 \mathrm{~m}$ more than the ice thickness estimation used in earlier studies (Sjögren and others, 2007). Ice thicknesses up to $250 \mathrm{~m}$ are found within tens of meters of the drilling site (Fig. 2).

Recently a dating method based on statistical extraction of historically known volcanic eruptions was used (Moore and others, 2012). To do this, the sulfate profile is fitted to all other ion species measured in the core using a multiple linear regression with moving windows in logarithmic concentration space (Moore and others, 2006). This allows the contributions of the several possible time-varying sulfate sources (other than volcanic) as well as the melt-induced relocation of ions and the heteroscedastic ion chromatography errors to be taken into account. In the sulfate residual obtained, peaks can only be related to stochastic sources (i.e. mainly volcanic). The significance of these peaks in the residual is found by assessing the variance within the sliding window used in the empirical regression. The chemical fingerprints of five volcanic eruptions were found (at 95\% confidence level) and among them a peak could be assigned to the Laki (Iceland) eruption (1783) at $103.6 \mathrm{~m}$ depth. The volcanic signatures could be used as reference horizons in a stacked Nye thinning model. Figure $3 \mathrm{~b}$ shows that the Nye ice thickness makes little difference to the dating except below $100 \mathrm{~m}$ depth. The closest fit to the volcanic reference layers is with a Nye depth of $300 \mathrm{~m}$. This is deeper than the depth from the radar (Fig. 2); however, it is consistent with the temperature profile (Fig. 3a) (Sommer, 2005). The extremely rugged topography will lead to ice dynamic flow far different from that assumed in the simple Nye model, so we use a thinning model with $300 \mathrm{~m}$ depth to compensate for the different vertical shear.

As described in Sections 3.3 and 3.4, Holtedahlfonna chemistry is dominated by ions originating mostly from marine and anthropogenic sources, with the volcanic sulfate fraction representing only $1.4 \%$ of the total sulfate budget (Moore and others, 2012). This rather weak volcanic signal explains why none of the five volcanic peaks could be detected previously with DEP measurements. For each horizon, the dating uncertainty, i.e. the difference between the eruption date and the dating model based on cycle counting (Divine and others, 2011), ranges from -0.9 years (for Agung, Indonesia, 1963) to +9.6 years (for Krakatau, Indonesia, 1883). The core age-depth scale calculated by Moore and others (2012) shows that the core covers a period of 305 years with a mean accumulation rate of $0.38 \mathrm{~m}$ w.e. $\mathrm{a}^{-1}$.

\section{RESULTS AND DISCUSSION}

\subsection{Snow accumulation and source of moisture}

For the period 1963-2005, i.e. for the upper $28.5 \mathrm{~m}$ of the Holtedahlfonna core, Van der Wel and others (2011) calculated an average annual accumulation rate on Holtedahlfonna of $0.50 \mathrm{~m}$ w.e. $\mathrm{a}^{-1}$, somewhat higher than the rate given by Kekonen and others (2005) for the period 1963-97 on Lomonosovfonna $\left(0.41 \mathrm{mw}\right.$.e. $\left.\mathrm{a}^{-1}\right)$. Van der Wel and others (2011) attributed this difference to Holtedahlfonna being located first on the trajectory of westerly storm tracks. For the earlier period 1783-1963, we found little difference in accumulation at Holtedahlfonna in contrast with Lomonosovfonna, where average annual snow accumulation rates are $\sim 20 \%$ greater over the recent period compared with the pre-1963 period (Fig. 3b). This result suggests a substantial difference in the responses of western and eastern Spitsbergen, concurrent with warming and increased moisture content of the Arctic troposphere (Morison and others, 2000; Groves and Francis, 2002). We shall show that this is likely due to different sea-ice histories on western and eastern Spitsbergen, which in turn impacts moisture availability, water isotopes and chemistry for Lomonosovfonna and Holtedahlfonna.

The oxygen isotope ratio in ice cores is commonly used as a tracer for the water cycle. Divine and others (2011) show that the $\delta^{18} \mathrm{O}$ of Svalbard ice cores is a useful proxy for regional winter air temperatures. Most of the $\delta^{18} \mathrm{O}$ signal is preserved in the annual layer despite percolation and refreezing (Van der Wel and others, 2011). The 10 year running means of the $\delta^{18} \mathrm{O}$ time series for the Holtedahlfonna and Lomonosovfonna ice cores are plotted in Figure 4. Although the amplitude of the isotopic variations is similar at both sites (between 1\%o and 3\% on average), the smoothed $\delta^{18} \mathrm{O}$ values are less negative in the Holtedahlfonna core and average $-14 \%$ over the whole period spanned by the core $(-16 \%$ for Lomonosovfonna). The similar altitude and latitude of Holtedahlfonna and Lomonosovfonna suggests similar cloud and surface temperatures, hence the difference in isotope values suggests either depletion due to longer transport pathways from a common source, or two different moisture sources. The short distance to the mostly non-seaice-covered Greenland Sea provides an obvious source involving travel of a further $100 \mathrm{~km}$ to reach Lomonosovfonna. In the Canadian Arctic, a $200 \mathrm{~km}$ difference in snow from a moisture source produces a $3 \%$ change in $\delta^{18} \mathrm{O}$ (Koerner, 1979), which compares with the 2\%o average difference between Holtedahlfonna and Lomonosovfonna for a $100 \mathrm{~km}$ distance difference to open water. Of course the Barents Sea will also provide a moisture source for both drill sites on some occasions, though in that case we would expect the deposition at Holtedahlfonna to be more depleted relative to Lomonosovfonna, hence this must be a relatively infrequent moisture source for Holtedahlfonna. An alternative explanation for the relatively higher $\delta^{18} \mathrm{O}$ values in Holtedahlfonna ice may be that part of the winter snow is removed at the coring site by wind scouring with resulting mean $\delta^{18} \mathrm{O}$ biased toward heavier values (Fisher and others, 1983, 1998). There are no direct data on seasonal distribution of snow accumulation and wind regime on Holtedahlfonna; however, data from radioisotope deposits suggest that wind scouring is not significant in these locations, as we discuss in the next subsection.

\subsection{Impact of post-depositional processes on glaciochemistry}

Experience from the Lomonosovfonna ice core leads us to expect that the Holtedahlfonna chemical records will be affected by significant seasonal surface melting, meltwater percolation and refreezing. In fact, for Lomonosovfonna, Van de Wal and others (2002) reported a firn temperature of 
$-2.8^{\circ} \mathrm{C}$ at $15 \mathrm{~m}$ depth, which, considering the mean annual air temperature at the drilling site is $-12.5^{\circ} \mathrm{C}$ (Pohjola and others, 2002a), results principally from transfer and release of latent heat by meltwater refreezing at depth. In his detailed stratigraphic study of shallow cores from Lomonosovfonna, Samuelsson (2001) found that meltwater does not normally penetrate further than 4 or $5 \mathrm{~m}$ depth. This is consistent with Kekonen and others (2005) who found that during the warmest years on Lomonosovfonna the percolation length ranges from two to eight annual layers. Holtedahlfonna borehole measurements (Sommer, 2005) reveal a firn temperature of $-0.4^{\circ} \mathrm{C}$ at $15 \mathrm{~m}$ depth (Fig. 3a) suggesting a greater impact of refreezing than on Lomonosovfonna. This is also reflected in the presence of more icy layers in the firn pack at Holtedahlfonna than at Lomonosovfonna. Grumet and others (1998) and Fisher and others (1998) showed that higher infiltration layer frequency generally implies the chemical signals are more affected by elution for Penny Ice Cap, Canadian Arctic. However, the opposite effect of ice layer formation, i.e. limiting the diffusion of the chemical signal (Hou and Qin, 2002), was shown by Van der Wel and others (2011) using highresolution tritium profiles from Holtedahlfonna and Lomonosovfonna, although it should be taken into account that the limited diffusion of radioactive isotopes is also inherent in their location within the ice crystal. The same study also indicates the 1963 tritium peak has the same amplitude in both ice cores and is consistent with other radioactivity measurement from other Svalbard ice cores (Pinglot and others, 1999). More particularly, ${ }^{137} \mathrm{Cs}$ on Lomonosovfonna has the same mean value at the summit drill site and at much lower altitudes on the glacier, ruling out any strong removal of snow or high-magnitude spatial noise induced by wind scouring (Pinglot and others, 1999).

As an overview of the role of melting and percolation in the post-depositional processes over the entire record, in Figure 5 we plot $\log \left(\left[\mathrm{Na}^{+}\right] /\left[\mathrm{Mg}^{2+}\right]\right)$, which has been defined as a good index of ion elution in Svalbard (lizuka and others, 2002; Grinsted and others, 2006) with higher values reflecting more melt. The Holtedahlfonna and Lomonosovfonna melt indices (10year running average) show some interesting dissimilarities (Fig. 5): variations in amplitude and frequency are larger for Holtedahlfonna, especially during the periods before 1740 and after 1970. These differences are especially visible during the 20th century, showing that Holtedahlfonna was more sensitive to melt than Lomonosovfonna. We found a significant correlation $(r=0.41, p \leq 0.05)$ between the Holtedahlfonna melt index and the summer air temperatures (June, July, August (JJA)) recorded at Svalbard airport (Longyearbyen) since 1911; for Lomonosovfonna the correlation coefficient is only 0.01 . Virkkunen and others (2007) found that for Spitsbergen glaciers, daily peak air temperature affects the amount of melting more than, for example, the duration of the summer or the number of positive degree-days. Assuming that Holtedahlfonna melt was well correlated with summer air temperature also before 1911, Figure 5 shows that, prior to 1860, daily maximum summer temperatures were lower and less variable than during the 20th century. The 1720 s might have seen the coldest summers of the last 300 years in Svalbard. The sharp rise in the melt index $\log \left(\left[\mathrm{Na}^{+}\right] /\left[\mathrm{Mg}^{2+}\right]\right)$ in the 1980s (Fig. 5) is closely matched with a pronounced decrease in concentration towards the detection limit for the nitrate and sulfate (Fig. 5), both of which are easily eluted
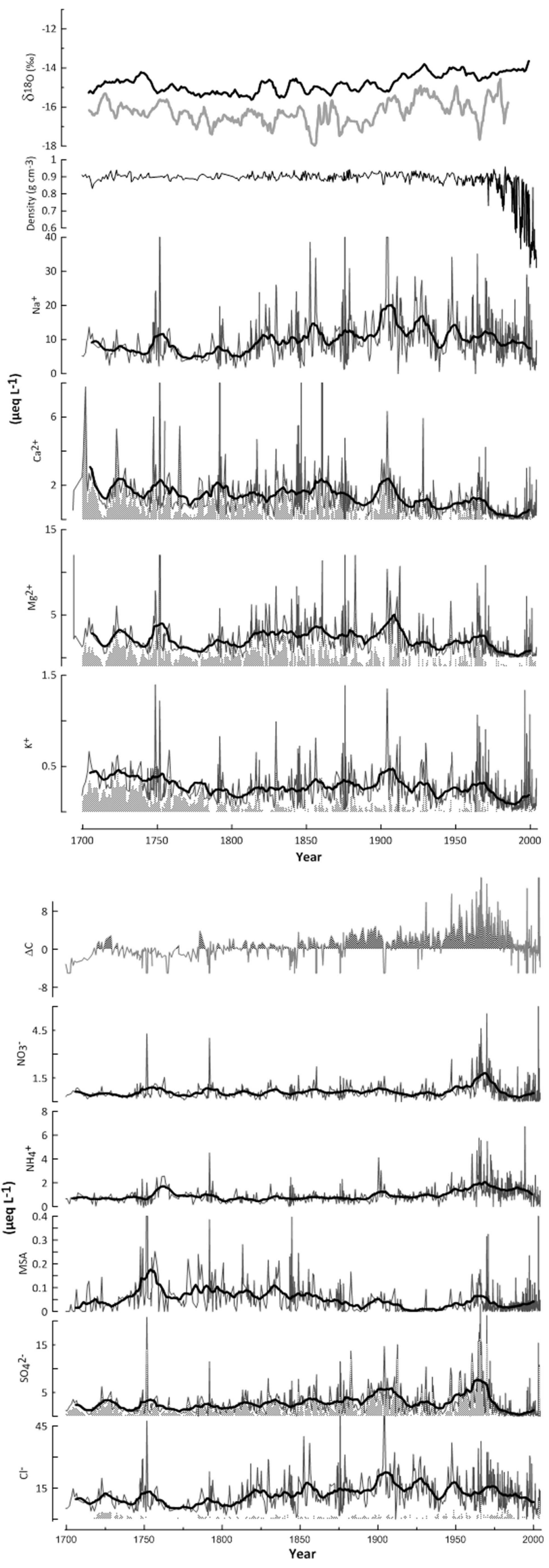

Fig. 4. Holtedahlfonna glaciochemical records (gray curves) at sample resolution with 10 year running average (black curve) and non-sea-salt fraction (light gray shaded area). Lomonosovfonna $\delta^{18} \mathrm{O}$ curve (10year running average) is shown in gray. The gray shaded area in the $\Delta C$ plot displays the acidic portion of the Holtedahlfonna core $\left(\Delta \mathrm{C}>0\right.$ with $\Delta \mathrm{C}=\sum$ anions $-\sum$ cations $)$. 


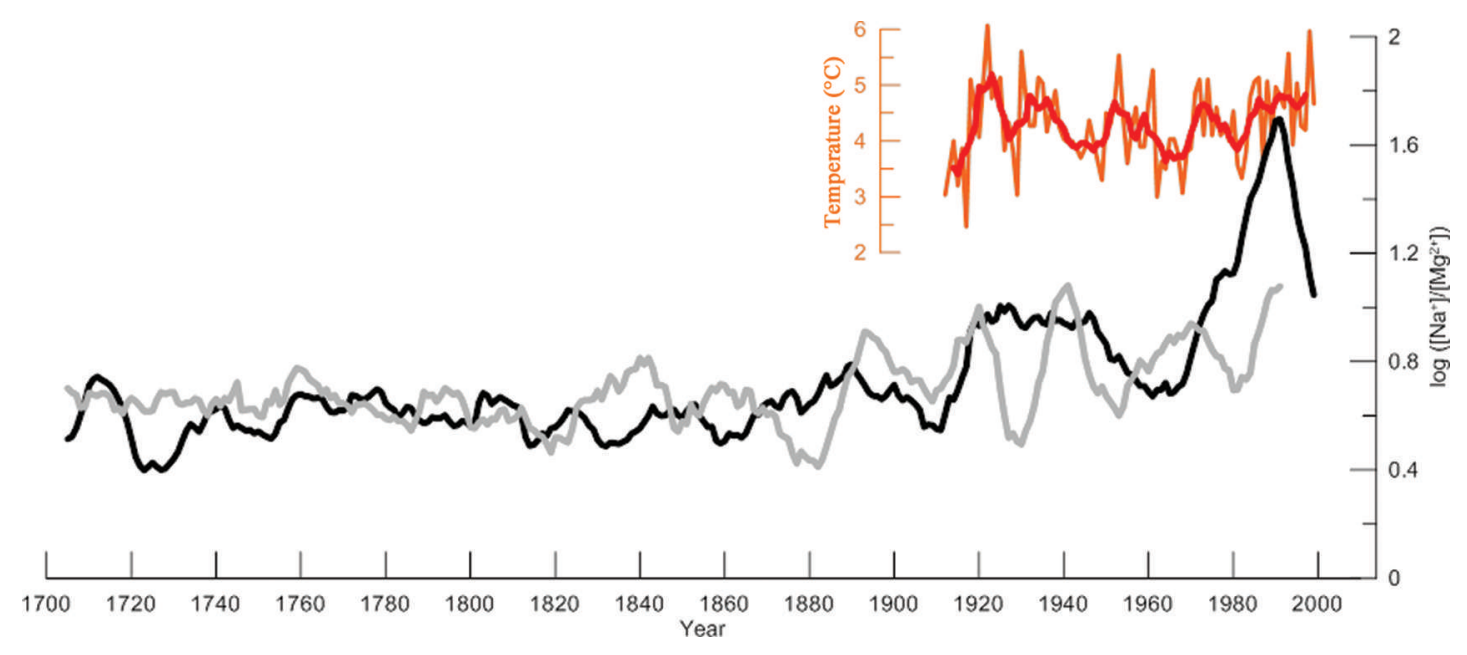

Fig. 5. Ten-year running average of the melt index $\left(\log \left(\left[\mathrm{Na}^{+}\right] /\left[\mathrm{Mg}^{2+}\right]\right)\right)$ for Holtedahlfonna (black curve) and Lomonosovfonna (gray curve); JJA mean (orange) and 5 year running average (red) air temperature recorded at Longyearbyen airport weather station $\left(78.25^{\circ} \mathrm{N}, 15.47^{\circ} \mathrm{E}\right.$; 29 ma.s.l.) between 1911 and 2000 (source: http://climexp.knmi.nl/).

components (Moore and others, 2005), and with lesser depletion for calcium, magnesium and potassium. Thus one hypothesis is that the ion concentrations are driven by postdepositional melt processes. This is consistent with the recent warming recorded by the melt index, with some of the more mobile ions species appearing to have been lost by runoff in recent decades. The impact of melt and runoff on ion chemistry has been long studied in seasonal snowpack (Davies and others, 1982), Alpine firn (Eichler and others, 2001) and Svalbard snow pits (Virkkunen and others, 2007). These and numerous other investigations show almost complete removal of ions during the first summer. This is a result of the location of most ions at grain boundaries in the snowpack, resulting in their preferential elution with meltwater. Ion concentrations in the firn remaining after a summer melt and washout are far lower than those observed in Holtedahlfonna except in some post-1980 ice (Fig. 4). Prior to 1980, the temporal evolution of these ions was similar to that found for Lomonosovfonna (Kekonen and others, 2002, 2005), which preserves a good record that is modified by melt but not runoff (Pohjola and others, 2002a). Hence we can reject the hypothesis that the chemical record

Table 1. Loading coefficients of each ion species obtained by EOF analysis of Holtedahlfonna and Lomonosovfonna major-ion standardized log-transformed data for the period 1700-1997. Bold numbers are the significant loadings

\begin{tabular}{lrrrr}
\hline & \multicolumn{3}{c}{ Holtedahlfonna } & \multicolumn{2}{c}{ Lomonosovfonna } \\
& EOF 1 & EOF 2 & EOF 1 & EOF 2 \\
& & & & \\
\hline $\mathrm{Cl}^{-}$ & $\mathbf{0 . 3 3}$ & $\mathbf{0 . 4 8}$ & $\mathbf{0 . 3 7}$ & 0.09 \\
$\mathrm{NO}_{3}{ }^{-}$ & $\mathbf{0 . 3 7}$ & 0.06 & $\mathbf{0 . 3 1}$ & $\mathbf{- 0 . 5 5}$ \\
$\mathrm{SO}_{4}{ }^{2-}$ & $\mathbf{0 . 4 3}$ & -0.05 & $\mathbf{0 . 3 4}$ & $\mathbf{- 0 . 2 7}$ \\
$\mathrm{MSA}$ & 0.16 & $\mathbf{- 0 . 3 4}$ & $\mathbf{0 . 3 0}$ & $\mathbf{0 . 2 0}$ \\
$\mathrm{NH}_{4}{ }^{+}$ & 0.07 & $\mathbf{0 . 4 4}$ & 0.17 & $\mathbf{- 0 . 6 6}$ \\
$\mathrm{K}^{+}$ & $\mathbf{0 . 3 7}$ & -0.12 & $\mathbf{0 . 3 5}$ & $\mathbf{0 . 2 1}$ \\
$\mathrm{Ca}^{2+}$ & $\mathbf{0 . 3 6}$ & $\mathbf{- 0 . 4 1}$ & $\mathbf{0 . 3 3}$ & 0.16 \\
$\mathrm{Mg}^{2+}$ & $\mathbf{0 . 4 1}$ & $\mathbf{- 0 . 2 2}$ & $\mathbf{0 . 4 0}$ & $\mathbf{0 . 2 3}$ \\
$\mathrm{Na}^{+}$ & $\mathbf{0 . 3 3}$ & $\mathbf{0 . 4 7}$ & $\mathbf{0 . 3 7}$ & 0.16 \\
Variance (\%) & 49.32 & 18.49 & 54.22 & 13.61 \\
Cumulative variance (\%) & 49.32 & 67.81 & 54.22 & 67.83 \\
& & & &
\end{tabular}

is simply post-depositional variability. However, we clearly need to take into consideration the tangled nature of variation in snow chemistry with post-depositional processes such as melt and percolation.

Moore and others (2005) performed an empirical orthogonal function (EOF) analysis on Lomonosovfonna ice-core samples to investigate the roles of precipitation and postdepositional movement of species in ice. Monte Carlo testing of the EOF factors (Moore and Grinsted, 2009) showed that the first eight EOFs were significant. Moore and others (2005) found that $60 \%$ of the variation in Lomonosovfonna data is due to elution and is the leading EOF. We use a similar approach for the Holtedahlfonna core, using log-transformed and standardized concentrations. The first six EOFs each correlate with one or several chemical species that are not distinctively representative of a single source or do not have a clear link with anything measurable. The first six EOFs account for a total of $95 \%$ of the variance (we expect $\sim 5 \%$ measurement noise errors, so no more than $95 \%$ variance can be expected to be physically explainable).

Table 1 displays only the two first eigenvectors, which together account for $68 \%$ of the variance; the first eigenvector (EOF 1) describes $49.3 \%$ of variance in the dataset. EOF 1 is loaded in all ions except ammonium and, to a lesser extent, MSA. Virkkunen and others (2007) showed that ammonium is the least mobile ion within the snowpack and has the lowest elution rate (Pohjola and others, 2002a) due to its solubility within the ice crystal. MSA has a higher elution rate than ammonium (Pohjola and others, 2002a; Moore and others, 2005) as it is a highly soluble acid that can move in the liquid or vapor phase along firn grain boundaries (Mulvaney and others, 1992) even in snowpack and firn well below the melting point (Kreutz and others, 1998; Pasteur and Mulvaney, 2000; Curran and others, 2002). However, at sites with seasonal melting, provided melting rate does not lead to ion loss by runoff, eluted ions are trapped by refrozen ice layers and prevented from longer diffusion and relocation. Furthermore, MSA variations in the Lomonosovfonna core were found to correlate significantly with Barents Sea surface temperatures (O'Dwyer and others, 2000), showing meaningful signals are preserved in the MSA record. Hence, as for Lomonosovfonna, about half of the variance of the Holtedahlfonna chemical dataset is due to 
Table 2. Average concentrations $\left(x\left(\mu \mathrm{eq} \mathrm{L}^{-1}\right)\right)$ and standard deviation $(\sigma)$ in (a) Holtedahlfonna and (b) Lomonosovfonna (Kekonen and others, 2005 ) in different time periods ( $n$ is the number of samples; \% nss is the non-sea-salt fraction over the period 1700-1997 calculated using sodium as a reference)

\begin{tabular}{|c|c|c|c|c|c|c|c|c|c|c|c|c|c|c|c|c|c|c|c|}
\hline \multirow[t]{2}{*}{ a } & \multicolumn{2}{|c|}{ MSA $\left(10^{-3}\right)$} & \multicolumn{2}{|c|}{$\mathrm{Cl}^{-}$} & \multicolumn{2}{|c|}{$\mathrm{SO}_{4}^{2-}$} & \multicolumn{2}{|c|}{$\mathrm{NO}_{3}^{-}$} & \multicolumn{2}{|c|}{$\mathrm{Na}^{+}$} & \multicolumn{2}{|c|}{$\mathrm{NH}_{4}^{+}$} & \multicolumn{2}{|c|}{$\mathrm{K}^{+}$} & \multicolumn{2}{|c|}{$\mathrm{Mg}^{2+}$} & \multicolumn{2}{|c|}{$\mathrm{Ca}^{2+}$} & \multirow[t]{2}{*}{$n$} \\
\hline & $x$ & $\sigma$ & $x$ & $\sigma$ & $x$ & $\sigma$ & $x$ & $\sigma$ & $x$ & $\sigma$ & $x$ & $\sigma$ & $x$ & $\sigma$ & $x$ & $\sigma$ & $x$ & $\sigma$ & \\
\hline Vho & .97 & 69.2 & .95 & 7. & 2.66 & 3.1 & .66 & 0 & 9 & 6.9 & 1.06 & 0.8 & 0.25 & 0. & 1.90 & 2.1 & 1.30 & 3.8 & 739 \\
\hline $1700-1815$ & 79.44 & 99.7 & 8.86 & 5.8 & 2.16 & 2.1 & 0.61 & 0.5 & 7.37 & 5.4 & 0.82 & 0.6 & 0.33 & 0 & 2.17 & 2 & 1.84 & 1.9 & 146 \\
\hline $1815-80$ & 63.33 & 60 & 12.83 & 8.6 & 2.78 & 2.1 & 0.59 & 0.3 & 10.91 & 8.5 & 0.72 & 0.4 & 0.28 & 0.2 & 2.84 & 2.2 & 2.28 & 7.6 & 166 \\
\hline 1880-1920 & 27.09 & 34.6 & 15.38 & 8.3 & 4.08 & 3.3 & 0.62 & 0.3 & 12.69 & 8.6 & 0.85 & 0.6 & 0.32 & 0.2 & 2.89 & 2.6 & 1.26 & 1 & 66 \\
\hline 1920-50 & 10.87 & 17.3 & 15.79 & 7.1 & 2.56 & 2.3 & 0.54 & 0.4 & 13.12 & 6.6 & 0.99 & 0.5 & 0.25 & 0.2 & 1.49 & 1.3 & 0.88 & 0.8 & 69 \\
\hline 1950-70 & 57.44 & 55.5 & 12.73 & 7.2 & 6.92 & 5.1 & 1.45 & 0.9 & 10.48 & 5.8 & 1.80 & 1.1 & 0.29 & 0.2 & 2.35 & 1.8 & 1.18 & 0.7 & 64 \\
\hline 1970-97 & 25.27 & 35.9 & 12.32 & 6.1 & 1.29 & 2.3 & 0.58 & 0.7 & 9.68 & 4.7 & 1.52 & 0.9 & 0.14 & 0.2 & 0.67 & 1.1 & 0.33 & 0.5 & 165 \\
\hline 1997-2004 & 45.72 & 97 & 7.39 & 6.4 & 1.38 & 2.5 & 0.59 & 1 & 6.65 & 6 & 0.83 & 0.5 & 0.20 & 0.2 & 0.95 & 1.3 & 0.70 & 0.7 & 65 \\
\hline$\%$ nss & & & 2.2 & & 55.7 & & & & & & & & 15.2 & & 22.8 & & 67.7 & & \\
\hline
\end{tabular}

\begin{tabular}{|c|c|c|c|c|c|c|c|c|c|c|c|c|c|c|c|c|c|c|c|}
\hline \multirow[t]{2}{*}{ b } & \multicolumn{2}{|c|}{ MSA } & \multicolumn{2}{|c|}{$\mathrm{Cl}^{-}$} & \multicolumn{2}{|c|}{$\mathrm{SO}_{4}^{2-}$} & \multicolumn{2}{|c|}{$\mathrm{NO}_{3}^{-}$} & \multicolumn{2}{|c|}{$\mathrm{Na}^{+}$} & \multicolumn{2}{|c|}{$\mathrm{NH}_{4}^{+}$} & \multicolumn{2}{|c|}{$\mathrm{K}^{+}$} & \multicolumn{2}{|c|}{$\mathrm{Mg}^{2+}$} & \multicolumn{2}{|c|}{$\mathrm{Ca}^{2+}$} & \multirow[t]{2}{*}{$n$} \\
\hline & $x$ & $\sigma$ & $x$ & $\sigma$ & $x$ & $\sigma$ & $x$ & $\sigma$ & $x$ & $\sigma$ & $x$ & $\sigma$ & $x$ & $\sigma$ & $x$ & $\sigma$ & $x$ & $\sigma$ & \\
\hline Whole core & 115.12 & 145.9 & 8.06 & 5.7 & 3.80 & 4.6 & 0.88 & 0.8 & 5.03 & 28.7 & 0.89 & 1.1 & 0.18 & 0.2 & 1.63 & 1.8 & 1.72 & 2.5 & 787 \\
\hline 1700-1815 & 124.81 & 98.4 & 7.39 & 4.2 & 3.07 & 4.1 & 0.68 & 0.4 & 2.67 & 13.5 & 0.06 & 0.2 & 0.18 & 0.1 & 1.60 & 1.2 & 1.59 & 2 & 214 \\
\hline 1815-80 & 143.90 & 161 & 8.28 & 6 & 2.90 & 3.3 & 0.86 & 0.8 & 3.47 & 11.5 & 1.24 & 0.7 & 0.23 & 0.2 & 1.82 & 1.8 & 2.07 & 2.8 & 222 \\
\hline 1880-1920 & 144.26 & 248.9 & 10.38 & 6.9 & 3.71 & 3.2 & 0.80 & 0.5 & 4.00 & 10.2 & 1.21 & 0.9 & 0.22 & 0.2 & 2.06 & 2.0 & 1.70 & 1.9 & 103 \\
\hline $1920-50$ & 63.88 & 91.6 & 9.17 & 6.1 & 5.15 & 5.5 & 0.71 & 0.6 & 8.94 & 27.2 & 0.82 & 0.6 & 0.11 & 0.1 & 1.79 & 2.1 & 2.57 & 3.8 & 88 \\
\hline 1950-70 & 92.51 & 90.9 & 7.56 & 5.4 & 7.49 & 8 & 1.46 & 1.1 & 17.57 & 88.5 & 1.52 & 2.4 & 0.15 & 0.2 & 1.54 & 2.5 & 1.03 & 1.1 & 63 \\
\hline 1970-97 & 58.12 & 72.7 & 5.90 & 5.1 & 3.95 & 4 & 1.20 & 1.2 & 3.18 & 6.8 & 1.20 & 1.2 & 0.07 & 0.1 & 0.70 & 0.8 & 0.88 & 1.5 & 97 \\
\hline$\%$ nss & & & 26.4 & & 74.3 & & & & & & & & 37.3 & & 29.7 & & 87.5 & & \\
\hline
\end{tabular}

post-depositional movement of ions, with the other half likely related to climatic factors. Therefore, to improve the signal-to-noise ratio and to take into account the signal fractionation due to elution, we use 10 year running means of the ion time series.

\subsection{Chemical composition of the Holtedahlfonna ice core}

Basic statistical properties of each ion and their non-sea-salt fraction at different periods on Holtedahlfonna and Lomonosovfonna are summarized in Table 2. Since we have no concrete evidence of the bedrock depth or layer thinning as a function of depth in the complex ice-flow regime around the drill site, we do not attempt to calculate fluxes of ions. Therefore, it is not possible to thoroughly conclude that ion concentrations in the Holtedahlfonna ice core are controlled by accumulation or dry deposition. However, Figure $3 \mathrm{~b}$ shows that accumulation rates vary little for most of the core, and in order to ease the comparison with the Lomonosovfonna ice-core dataset (Kekonen and others, 2005) we will use concentrations rather than fluxes in the discussion of our results.

Almost all ion (chloride, sulfate, nitrate, ammonium, sodium, potassium, magnesium) concentration profiles (Fig. 4) display an increase from 1815. Calcium and MSA are exceptions, and their average concentrations during the period 1700-1815 were $\sim 50 \%$ higher than after 1815 (Table 2). Sodium, chloride and potassium do not show significantly higher concentrations during the coldest part of the LIA, culminating at about 1850 in Svalbard (Divine and others, 2011) and between 1800 and 1840 in the Arctic as a whole (Overpeck and others, 1997). In contrast, magnesium concentrations are $>50 \%$ higher during 1750-1880 and are dominated by the terrestrial fraction (Fig. 4), as was also observed in Canadian Arctic and Greenland ice cores (Mayewski and others, 1993).

The ice is distinctly acidic from 1850, which corresponds to the onset of the industrial revolution in Europe $(\Delta C>0$; Fig. 4), and even more so between 1940 and 1980 when human activity (fossil-fuel burning) significantly enhanced the level of acidic species such as nitrate, nss-sulfate, nsschloride, probably deposited as nitric acid $\left(\mathrm{HNO}_{3}\right)$, sulfuric acid $\left(\mathrm{H}_{2} \mathrm{SO}_{4}\right)$ and hydrochloric acid $(\mathrm{HCl})$ brought by Arctic haze (Virkkunen, 2004). Sulfate concentrations have risen by a factor of 1.7 since 1880 . The major part of the increase occurred after 1940. Peak levels are reached during the 1960s, which is consistent with ice-core records from Snøfjellafonna, Svalbard (Goto-Azuma and others, 1995) and from Severnaya Zemlya, Russian arctic (Weiler and others, 2005), but contrasts with Greenland and the Canadian Arctic (Grumet and others, 1998), which display a more gradual rise in sulfate over the 20th century. It is likely that these ice cores from Greenland and Canada are more representative of the Northern Hemisphere tropospheric concentration (Fisher and others, 1998). In the Holtedahlfonna core, the average concentration of ammonium is 2.2 times higher during the 20th century than during the 18th century (Table 2).

\subsection{Comparison with the Lomonosovfonna ice core}

Since ion chromatograph data are heteroscedastic (in this case errors are proportional to concentration) and postdepositional processes affect ion elution rates (Moore and others, 2005), calculation of statistics assuming normality and non-sea-salt ratios is suspect; however, these measures are still commonly used and may be useful for comparing 
similar cores providing all concentration data are logtransformed. On average over the last three centuries, the number of species with a dominant sea-salt source $\left(\mathrm{Na}^{+}, \mathrm{Cl}^{-}\right.$, $\mathrm{K}^{+}, \mathrm{Mg}^{2+}$; Table 2) is larger in Holtedahlfonna than Lomonosovfonna. At both sites, sulfate is the third largest contributor to the ion budget although its proportion of the sum in Holtedahlfonna ice is only half that in Lomonosovfonna. The nss-sulfate contribution to the total sulfate concentration is also on average much smaller on Holtedahlfonna (55\%) than on Lomonosovfonna (74\%). Moore and others (2012) estimate that the volcanic sulfate fraction on Holtedahlfonna is less than half that on Lomonosovfonna.

The greater total amount of sea salt as well as the smaller fraction of nss-sulfate at Holtedahlfonna may reflect the shorter distance from the marine aerosol source to Holtedahlfonna summit compared with Lomonosovfonna. The marine biogenic fraction of sulfate, estimated by MSA concentrations, is surprisingly low at Holtedahlfonna, with an average concentration less than half that of Lomonosovfonna (0.05 and $0.12 \mu \mathrm{eq} \mathrm{L}^{-1}$, respectively). This probably points to a difference in the primary productivity of the marine source, implying two different marine origins with respectively low and high primary productivity. This latter point is discussed further in Section 3.5.

The difference in the calcium budget and the relative proportion of terrestrial calcium in the two ice cores also reveals the more proximal and influential sea-salt source for Holtedahlfonna. While Kekonen and others (2005) report that over the common period between the cores (17001997), $88 \%$ of calcium in Lomonosovfonna ice is of terrestrial origin, we calculate that on Holtedahlfonna this fraction is more limited and represents only $68 \%$. Nevertheless this observation should be moderated when comparing the different periods. For example, Holtedahlfonna received on average about the same amount of terrestrial calcium as Lomonosovfonna during most of the 18th century (1700-80; 1.52 and $1.56 \mu \mathrm{eq} \mathrm{L}^{-1}$, respectively) and twice as much between 1950 and 1970 (0.72 and $0.36 \mu \mathrm{eq} \mathrm{L}^{-1}$, respectively).

Proportions of ammonium and nitrate are slightly smaller in Holtedahlfonna than in Lomonosovfonna for the same period.

\subsection{Biogenic source productivity}

As an oxidation product of gaseous biogenic dimethylsulfide (DMS) emissions (Dacey and Wakeham, 1986), MSA is commonly used as a proxy for marine biogenic productivity. Isaksson and others (2005a) suggested that sea-ice extent was likely the dominant effect on the variability of MSA concentrations in Lomonosovfonna ice and also hypothesized that the higher MSA concentration during the colder 19th century could result from a change of source and/or from more favorable growing conditions for the DMSproducing phytoplankton during the prevailing colder conditions. For the 20th century, O'Dwyer and others (2000) found that Lomonosovfonna MSA better correlated with Barents Sea surface temperature and ice cover than with the Greenland Sea conditions, indicating that the amount of MSA deposited on Lomonosovfonna is very much influenced by the conditions in the Barents Sea.

Similarly to Lomonosovfonna, the Holtedahlfonna core contains more MSA on average during part of the cold period 1700-1880 $\left(0.07 \pm 0.08 \mu \mathrm{eq} \mathrm{L}^{-1}\right)$ than during the 20th century $\left(0.03 \pm 0.05 \mu \mathrm{eq} \mathrm{L}^{-1}\right)$. The MSA concentrations in
Holtedahlfonna remain lower than those in Lomonosovfonna throughout the last three centuries, suggesting a different and/ or less productive marine source influencing western Spitsbergen. The transition from the LIA to the warmer 20th century is more marked in Holtedahlfonna records, with 20 th-century concentrations being $43 \%$ of LIA values, than at Lomonosovfonna when MSA concentrations dropped to $66 \%$ of earlier levels (Fig. 6a). These decreases slightly precede the change in sea-ice cover in the Greenland Sea at $\sim 1880$ (Divine and others, 2008) creating on the western side of Spitsbergen year-round open-water conditions. Figure $6 \mathrm{~b}$ displays the maximum (April) and minimum (August) seasonal sea-ice extent anomalies for the Greenland Sea and shows the larger annual ice extent amplitude before 1885 compared with the 20th century. The reduction in annual seaice amplitude (i.e. the difference between April and August sea-ice extent) corresponds with the low MSA concentrations in Holtedahlfonna. Correlation between the 10 year running average time series of MSA and the 10 year running average of the Greenland Sea April ice extent anomaly for the period $1762-1880$ is higher than with the Barents Sea ice extent anomaly; coefficients are significantly different $(0.46$ $(p<0.05)$ and 0.10 , respectively) and suggestive of a connection between positive Greenland Sea ice anomalies and high MSA levels at Holtedahlfonna during the LIA.

These results may be expected as the more extensive seasonally ice-covered western side of Svalbard during the LIA leads to increased production of meltwater, thereby stabilizing the water column in spring and summer, which may have favoured biomass production in the euphotic zone and thus enhanced release of DMS in the atmosphere (Strass and Nöthig, 1996; Sakshaug and Walsh, 2000). A similar process also might have taken place in the Barents Sea (Isaksson and others, 2006a), with a wider seasonally icefree area creating a stronger DMS source on eastern Svalbard being recorded in Lomonosovfonna ice. Records of higher MSA concentration for the 19th century in Holtedahlfonna are in accordance with those from Greenland ice cores. A negative relationship between the Greenland Sea surface temperature and MSA concentrations in the 20D (southern Greenland) ice core was found by Whung and others (1994) over the period 1870-1950, and Legrand and others (1997) suggest that such a correlation, also demonstrated for MSA records from Summit, central Greenland, may result from increased sea-ice extent during cold periods causing higher DMS emissions in the atmosphere.

The relationship between MSA and Greenland Sea ice extent, as well as the MSA concentration difference between Holtedahlfonna and Lomonosovfonna, seems to imply that the biogenic productivity of the Greenland Sea was weaker than that of the Barents Sea during the 19th century. However, this does not rule out the possible contribution of lower-latitude air masses to the Holtedahlfonna MSA budget. The MSA fraction of nss-sulfate is known to increase with latitude and has often been used to investigate the possible origin of marine air masses (Bates and others, 1992). This is based on the fact that DMS oxidation by $\mathrm{OH}$ radicals (the dominant oxidant in a clean atmosphere) is temperaturedependent as the additional pathway producing MSA is favored at low temperature (Hynes and others, 1986; Seinfeld and Pandis, 1998). Between 1700 and 1920 the MSA fraction, i.e. MSA/(MSA + nss-SO ${ }_{4}$ ) (Fig. 6c), in Holtedahlfonna is fairly consistently $3 \%$ lower than that of Lomonosovfonna while the Greenland MSA fraction (10-20\%) 

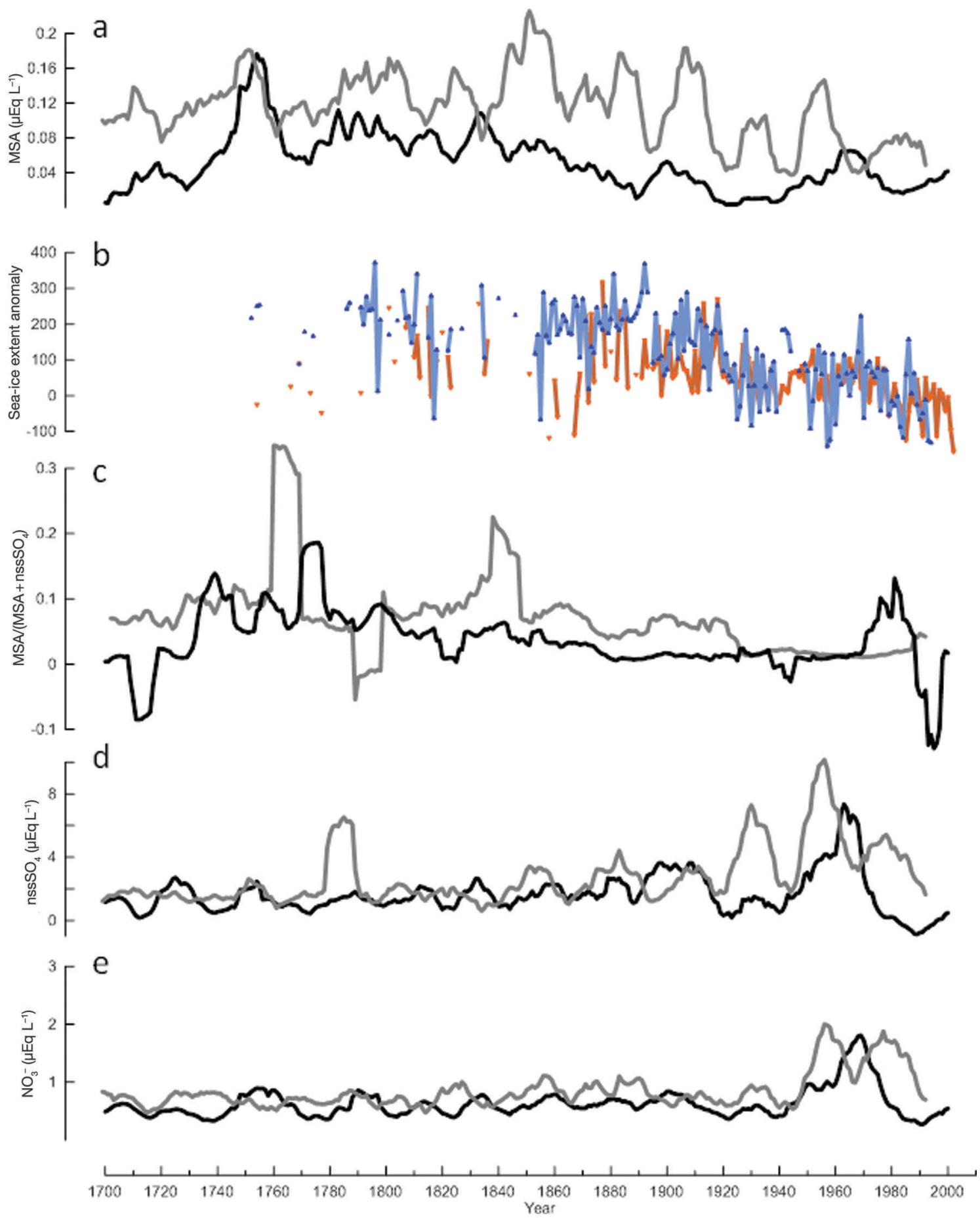

Fig. 6. Ten-year running average for Holtedahlfonna (black) and Lomonosovfonna (gray) of (a) MSA concentrations, (b) April (blue) and August (orange) sea-ice extent anomaly for the Greenland Sea ice (Divine and Dick, 2006; data are not available for every year) (note the decrease in amplitude of seasonal variability in sea-ice extent at 1880), (c) MSA fraction, with a mean of $8 \%$ for Holtedahlfonna prior to 1880 and $1 \%$ after that, (d) nss-sulfate $\left(\mathrm{nssSO}_{4}\right)$ concentrations and (e) nitrate $\left(\mathrm{NO}_{3}{ }^{-}\right)$; note that the profiles are uncorrelated with MSA.

(Legrand and others, 1997) is more similar to Lomonosovfonna in the LIA than Holtedahlfonna. The MSA fraction shows marked variability during the LIA compared with the 20th century at Holtedahlfonna, consistent with the much reduced sea-ice cover in the Greenland Sea and especially the reduced amplitude of seasonal variations. After 1920, Lomonosovfonna and Holtedahlfonna have a very similar MSA fraction, which is linked to the retreat of the sea-ice margin in the Barents Sea at that time (Divine and others, 2008). The Holtedahlfonna MSA fraction is negative or zero before 1730. This pattern in the Holtedahlfonna record could be the consequence of a smaller difference between April and August sea-ice extents in the Greenland Sea at the beginning of the 18th century, which could have resulted from colder summers (see Section 3.2) and limited ocean heat loss in summer in the 1720s.

The loss of ions through runoff is responsible for the negative fraction seen after 1980 at Holtedahlfonna. The generally lower MSA fraction compared with Lomonosovfonna either constitutes more evidence for a different marine biogenic source influencing western Spitsbergen or points to an additional source of nss-sulfate for Holtedahlfonna, which 


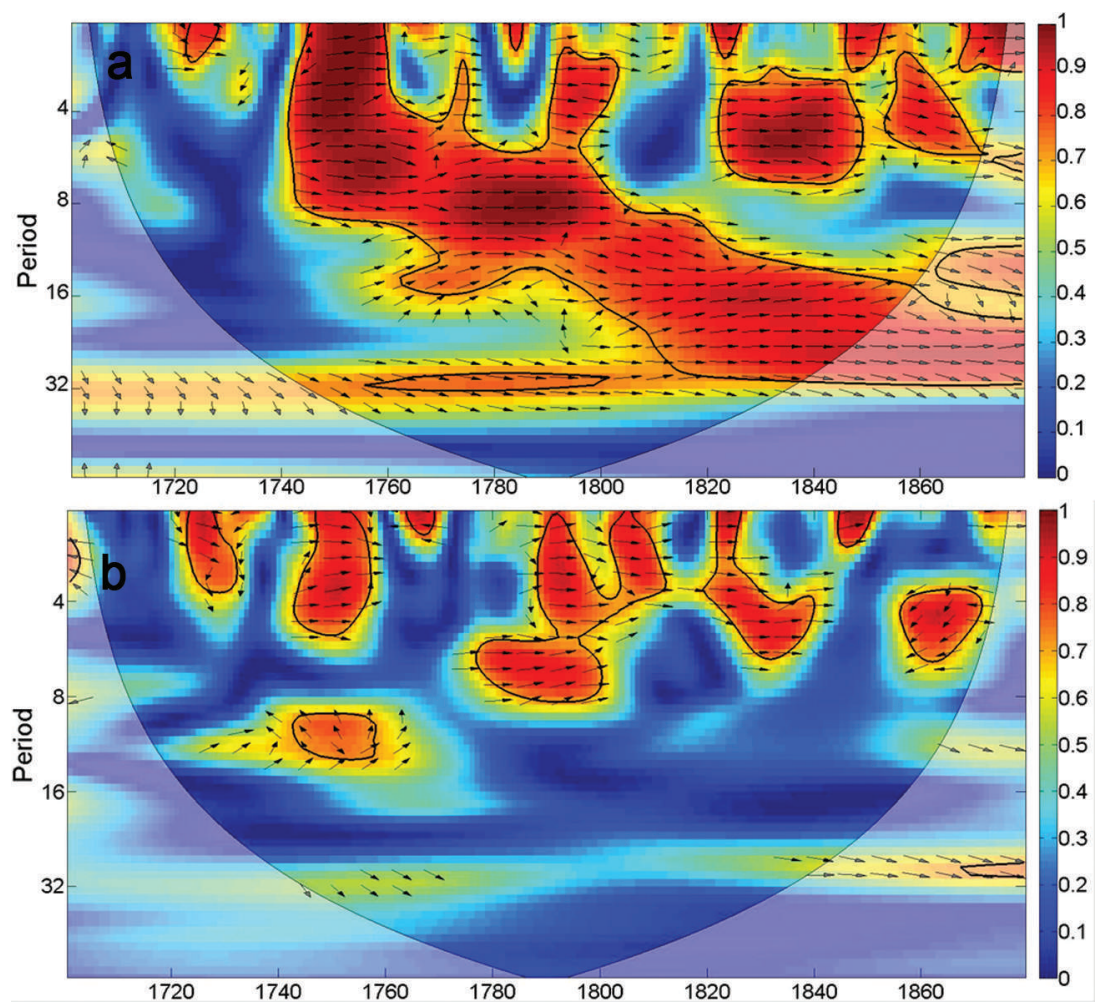

Fig. 7. Wavelet coherency and phase in Holtedahlfonna between (a) MSA and nss-sulfate and (b) nssCa and nss-sulfate. The thick black contour designates the $5 \%$ significance level against red noise, and the thin black curve is the cone of influence. Arrows pointing to the right indicate in-phase relative relationship.

could be terrestrial biogenic, continental (gypsum dust) or volcanic. Any significant volcanic contribution is unlikely as the fraction of volcanic sulfate in Holtedahlfonna is very low $(1.4 \%)$ in comparison with that of Lomonosovfonna $(4.5 \%)$ (Moore and others, 2006, 2012) or Greenland (57\%) (Legrand and others, 1997). We can use wavelet coherence (WTC; Grinsted and others, 2004) to investigate the relationship between MSA and nss-sulfate (Fig. 6d) variations. Between 1700 and 1880 (Fig. 7) the time series are highly coherent (WTC > 0.8) and in phase at almost all periods. This contrasts with a smaller and more disjointed significant area in the WTC plot for nss-calcium and nss-sulfate (Fig. 7).

The correlation between MSA and nss-sulfate argues in favor of a dominant biogenic source of nss-sulfate in Holtedahlfonna during the 18th and 19th centuries. Since DMS can also be oxidized by radicals other than $\mathrm{OH}$ producing sulfur dioxide $\left(\mathrm{SO}_{2}\right)$ or sulfate instead of MSA, the interpretation of the MSA fraction in terms of the biogenic source latitude (or temperature) is not straightforward when the oxidative capacity of the atmosphere changes. The most efficient atmospheric oxidants of DMS are $\mathrm{OH}, \mathrm{BrO}$ and nitrate, whereas others such as $\mathrm{Cl}, \mathrm{IO}$ and $\mathrm{O}_{3}$ are less efficient (Barnes and others, 2006). Yet Whung and others (1994) argue that, despite the substantial $\mathrm{NO}_{\mathrm{x}}$ levels in the Arctic atmosphere during the industrial period, $\mathrm{NO}_{3}{ }^{-}$oxidant does not control the MSA concentration in Greenland ice cores because nitrate is photolyzed before DMS emissions reach their maximum in spring/summer. Similarly, in the Holtedahlfonna core, the sharp increase in nitrate $\left(\mathrm{NO}_{\mathrm{x}}\right)$ (see Fig. 9e, further below) did not lead to a decrease in MSA. In summer, only $\mathrm{OH}$ and $\mathrm{BrO}$ may compete efficiently in oxidizing the DMS. For instance, recent measurements of $\mathrm{BrO}$ made over 1 year by Saiz-Lopez and others (2007) at Halley, Antarctica, indicate a mean level of 3 pptv during
January-March. Such high BrO levels in summer make the $\mathrm{BrO}$ reaction on DMS producing MSA four times faster than that with $\mathrm{OH}$ (addition pathway) (Read and others, 2008). Since numerous studies suggest that the bromine chemistry is promoted by sea-ice coverage we cannot exclude the possibility that the decrease in sea ice was accompanied by decreasing halogen chemistry and may have contributed to the decrease of the MSA fraction between 1700-1880 and recent decades. Additionally, the increases of nss-sulfate are similar at Holtedahlfonna and Lomonosovfonna (Fig. 6d; Table 2), so we ascribe the sharp change of MSA in Holtedahlfonna at $\sim 1880$ to the rapid decline in sea-ice cover in the Greenland Sea and the relatively larger temperature rise at the end of the LIA than occurred in the wider North Atlantic (Engelsen and others, 2002).

\subsection{Ammonium variability}

Lomonosovfonna and Holtedahlfonna display divergent behavior of ammonium around the end of the LIA (Fig. 4). The 10 year running mean ammonium values in the Lomonosovfonna core follow a decreasing trend from 1900 to 1940 before reflecting the impact of anthropogenic pollution in the 1950s (Fig. 8a) (Kekonen and others, 2002). In contrast, Holtedahlfonna ammonium concentrations rise by a factor of 3 starting in 1880. Explanations for the earlier rise of ammonium concentration could be that it either reflects a more efficient ammonium transport to Holtedahlfonna or that during the period 1880-1940 Holtedahlfonna received an additional source of ammonium compared with Lomonosovfonna. In relation to the regional climate component discussed in Section 3.1, local wetland formed by the reduction of snow-covered areas at the end of the LIA might have constituted a source of local gaseous ammonia $\left(\mathrm{NH}_{3}\right.$, a precursor of ammonium) influencing the 


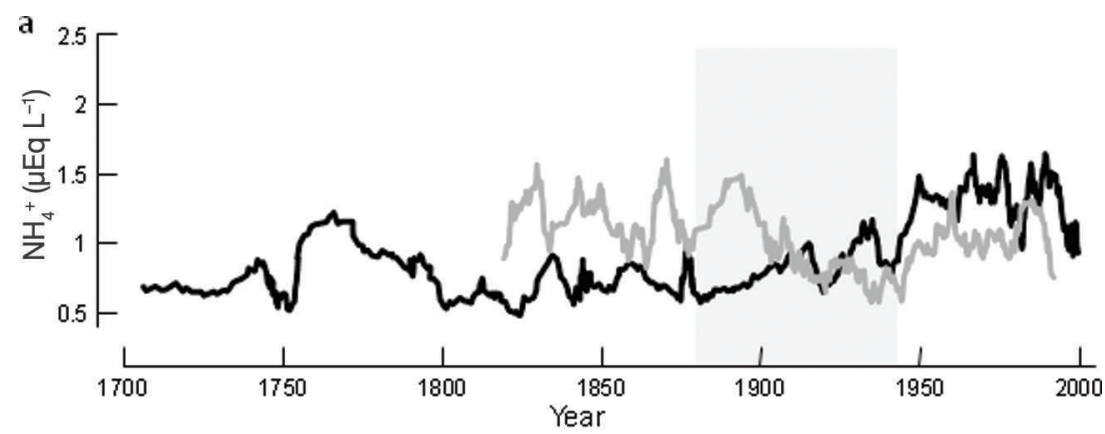

b

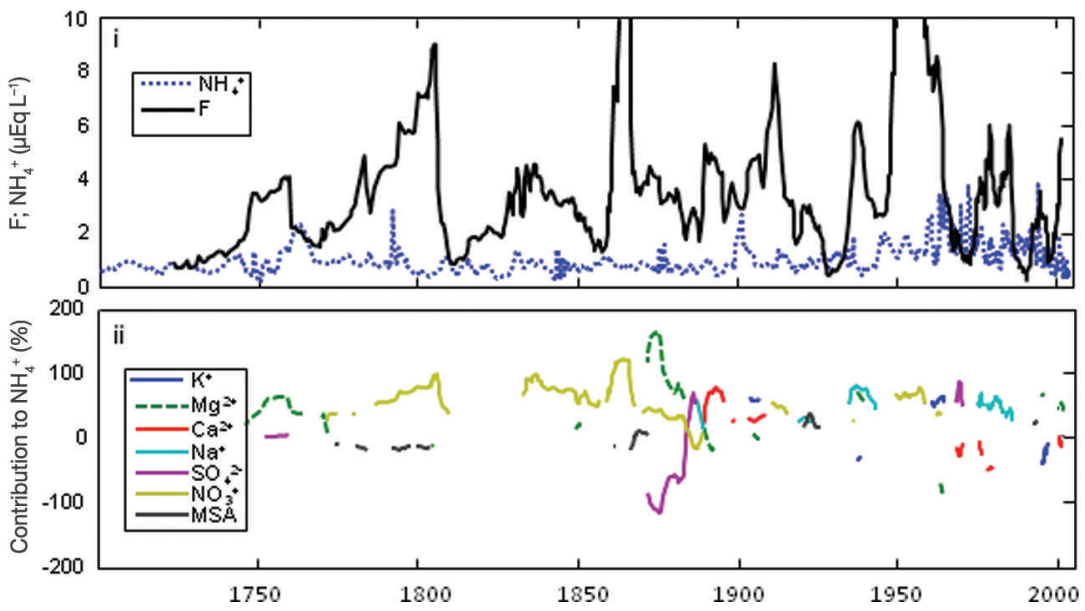

Fig. 8. (a) Ten year running average concentrations of ammonium ( $\mu \mathrm{eq} \mathrm{L}^{-1}$ ) in Holtedahlfonna (black) and Lomonosovfonna (gray) cores. The shaded area indicates the Little Ice Age (LIA) termination. (b) Holtedahlfonna ammonium multiple linear regression (MLR): (i) sample-bysample ammonium ion concentration profile (blue dotted curve) and the F statistic for the 100 points windowed MLR; (ii) contributions of each species in the MLR to the ammonium concentration (see Moore and others (2006) for method details), the ion curves are only plotted when their contribution is significant at the $95 \%$ level. Most of the record is dominated by covariation with nitrate (light green). After 1880 , no ion stands out as generally covarying with ammonium, though sometimes both sodium $\left(\mathrm{Na}^{+}\right.$; turquoise) and sulfate $\left(\mathrm{SO}_{4}{ }^{2-}\right.$; purple) are important factors.

Holtedahlfonna ammonium budget. However, the lack of data on wetlands for the Svalbard region makes it impossible to verify this hypothesis.

Jickells and others (2003) used stable $\mathrm{N}$ isotopes in ammonium to derive sources of ammonium. However, we have only ion concentration data, so we use an indirect approach. To investigate the temporal evolution of the contributions to the ammonium budget along the core we performed a multiple linear regression (MLR) between ammonium and other ions (Fig. 8b). This innovative procedure is essentially the same as that used to evaluate the sulfate budget in Lomonosovfonna described by Moore and others (2006) and the first steps of finding the volcanic sulfate residuals (Moore and others, 2012; Section 2.3), but rather than modeling sulfate as a function of the other ions, here we target ammonium by fitting the other ions.

During the pre-industrial period until 1880, nitrate is the most significant cofactor with ammonium, indicating the existence of natural ammonium nitrate $\left(\mathrm{NH}_{4} \mathrm{NO}_{3}\right)$, a compound formed more favorably in cold conditions (Battye and others, 2003; Teinilä and others, 2003). The North American soil, vegetation and biomass-burning $\mathrm{NH}_{3}$ emissions constitute the main pre-industrial source of ammonium for Greenland and reflect the propensity of polar ice sheets to sample the free troposphere where $\mathrm{NH}_{3}$ and ammonium residence times allow their long-range transport (Fuhrer and others, 1996). Yet the oceanic source of $\mathrm{NH}_{3}$ in the Arctic is considered non-negligible, especially in winter (Fisher and others, 2011). Jickells and others (2003) provided evidence for a substantial marine ammonia winter source. The ocean constitutes a net source of $\mathrm{NH}_{\mathrm{x}}$ (i.e. $\mathrm{NH}_{3}$ and $\mathrm{NH}_{4}{ }^{+}$) to the continents during pre-industrial times, with smaller seawater $\mathrm{NH}_{\mathrm{x}}$ concentrations in regions of low primary productivity (nutrient-limited communities being more efficient at utilizing recycled nitrogen and thus maintaining a lower ambient concentration; Spokes and others, 2000; Johnson and others, 2008 and references therein).

Depending on which of the natural sources (oceanic or continental) dominates the Svalbard ammonium budget, the lower pre-industrial ammonium concentration measured in Holtedahlfonna ice compared with Lomonosovfonna could: (1) be an additional argument in favor of a cold and low productive marine source for western Spitsbergen compared with eastern Spitsbergen, which is more influenced by the North Atlantic where $\mathrm{NH}_{3}$ sea-air fluxes are one order of magnitude higher (Johnson and others, 2008); or (2) indicate that Holtedahlfonna is less influenced by the free troposphere than Lomonosovfonna. After 1880, the nitrate covariation and fractional contribution to ammonium becomes insignificant and none of the other ions becomes a consistent replacement in the MLR (Fig. 8b). Over a period when melting impact rises constantly, this probably reflects the specific elution-resistant behavior of ammonium (Table 1). This may be the case during the 1980s when higher ammonium concentrations are not correlated with nitrate or sulfate (Fig. 4). 

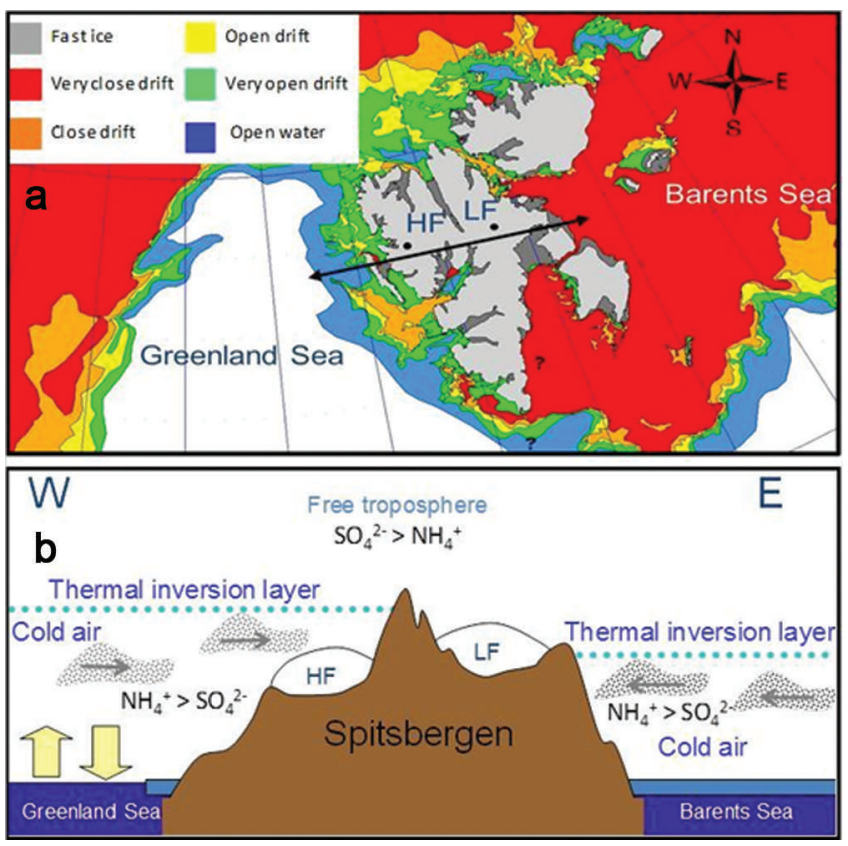

Fig. 9. (a) Map of Svalbard and surrounding seas showing presentday typical sea-ice conditions in winter (source: http://retro.met.no/ kyst_og_hav/iskart.html). The black double-headed arrow marks the west-east profile section of Spitsbergen through Holtedahlfonna (HF) and Lomonosovfonna (LF) represented in (b). (b) Winter-spring Arctic haze situation and the vertical stratification of aerosol acidity (Fisher and others, 2011). The process shown in this figure applies for the present time.

Virkkunen and others (2007) showed that the chemical fingerprint of anthropogenic ammonia $\left(\mathrm{NH}_{3}\right)$, sulfur dioxide $\left(\mathrm{SO}_{2}\right)$ and nitrogen oxides $\left(\mathrm{NO}_{\mathrm{x}}\right)$ (the main constituents of the Arctic haze) was present in 2001/02 snowpack on Holtedahlfonna but absent on Lomonosovfonna. The rise of ammonium in Holtedahlfonna records starting in 1880 could result from mid-latitude pollution reaching the Arctic in late winter when meridional transport intensifies (Iversen and Joranger, 1985). The global $\mathrm{NO}_{\mathrm{x}}$ emissions started to rise in the 1860s (Klimenko and others, 2000). Anthropogenic ammonium pollution is also detected from 1870 in the Colle Gnifetti (Italy/Switzerland) ice core (Döscher and others, 1996) and at least from 1920 in Col du Dôme, France (Fagerli and others, 2007), while no increasing trend is visible before the 1940-1950s in Greenland (Fuhrer and others, 1996), Qomolangma (Mount Everest; Hou and others, 2003) or Lomonosovfonna (Kekonen and others, 2005) records.

To account for the absence of Arctic haze from Lomonosovfonna snow, Virkkunen and others (2007) invoked geographical factors such as the orientation of the surrounding fjords. Here we advocate the respective positions of the two glaciers relative to the top of the atmospheric boundary layer within which neutralized pollutants are transported from continental source areas in late winter. The acidity of Arctic haze aerosols depends on the availability of ammonia to neutralize sulfate. Using aircraft and surface aerosol data (including data from Zeppelin station), Fisher and others (2011) investigated the source contributing to ammonium, sulfate and aerosol acidity through the depth of the Arctic troposphere over the winter-spring season. For the winter season, they found that sulfate and ammonium sources are more stratified than later in spring. Aerosols in the free troposphere are more acidic and are dominated by sulfate (originating mostly from east Asia), whereas more abundant and neutralized aerosols (from west Asia and Europe) remain within the boundary layer.

As shown in Figure 9, the shorter distance of Holtedahlfonna to the quasi-permanent open sea (the Greenland Sea) could facilitate oceanic heat advection to the ice cap in summer and in winter allow some vertical convection, thereby weakening the temperature inversion gradient and slightly raising its upper boundary, placing Holtedahlfonna within the inversion layer (Solberg and others, 1996; Treffeisen and others, 2007). Conversely, the presence of ice-covered sea on the eastern side of Spitsbergen would provoke an intensive radiative cooling of the lower troposphere, leading to the formation of a very stable and hence thin inversion layer during the polar night $\mathrm{Wu}$ and others, 2004; Koenigk and others, 2009). In those conditions Lomonosovfonna would be located above the thermal inversion layer and would most likely collect pollution from the more acidic free troposphere in winter. This contrasts with the summer configuration when the northern position of the sea-ice margin makes the Barents Sea water stratification propitious to algal bloom, which then forms a local source of MSA (and sea salt) for Lomonosovfonna (see Section 3.5). The atmospheric vertical stratification of acidity in winter could then also explain why Svalbard's highest sulfate and greater acidity levels are recorded in Lomonosovfonna (Kekonen and others, 2005) (Fig. 7).

\section{CONCLUSIONS}

We have presented ion chemical data for the past 300 years from Holtedahlfonna and compared them with records extracted from the Lomonosovfonna core to illustrate sitespecific climatic and glaciological factors and better estimate the local influence of environmental factors on ice records in the Svalbard setting. Despite the fact that the melt index is on average higher in Holtedahlfonna, melting is responsible for $49 \%$ of the variance in ion concentration, which is almost the same as that estimated for the Lomonosovfonna ice core $(55 \%)$. This is likely because of the formation of thin layers of ice in the annual snowpack, which act as barriers to the deeper elution of ions, helping to preserve a multi-year resolution environmental record. Holtedahlfonna chemical melt index $\left(\log \left(\left[\mathrm{Na}^{+}\right] /\left[\mathrm{Mg}^{2+}\right]\right)\right)$ is a better proxy for Svalbard 20th-century summer air temperatures than provided by other ice cores from the archipelago.

A strong local response is also shown in the spatial and temporal variability of chemical species. As expected, we found that Holtedahlfonna ice contains more sea salt due to its proximity to the Greenland Sea, which is ice-free almost throughout the year. The lower MSA and ammonium levels measured for the LIA compared with those measured in Lomonosovfonna also argue in favour of the influence of a local marine source with lower primary productivity (a cooler source) during this period. The good correlation between Greenland Sea ice extent and Holtedahlfonna biogenic sulfur record (MSA) supports this hypothesis and reveals the complex air-sea-ice interactions that characterize the Greenland Sea compared with other Nordic seas (Kvingedal, 2005).

In addition to providing a proximal source of warmth, moisture, sea salt and biogenic sulfur to western Svalbard, 
the low ice concentration of the Greenland Sea favors the altitudinal dispersal of tropospheric pollution. The study of the ammonium budget suggests that either the open sea provides a winter source of ammonium or, just as consistently, that the glaciers of the western part of Spitsbergen, such as Holtedahlfonna, may better reflect the tropospheric boundary layer pollution burden than do eastern glaciers, which are more representative of the free troposphere in winter. The small sea-ice extent in the Greenland Sea strongly influences the height of the winter inversion layer and thus the delivery of more neutralized Arctic haze aerosols to the glacier. As Arctic warming progresses we may expect drastic retreat of the Barents Sea seasonal ice cover. The analysis of the Holtedahlfonna ice core foretells how glaciochemical signals from eastern Svalbard glaciers (such as Lomonosovfonna) could be altered and how winter-spring pollution would be mixed higher in the Arctic troposphere.

\section{ACKNOWLEDGEMENTS}

We thank the Norwegian Polar Institute, the Dutch Science Foundation (NWO) and the Swedish Science Council (VR) for funding the ice-core drilling, and Kristiina Virkkunen and Venkata Gandikota for the primary cutting of the ice core. We also thank the Finnish Forest Research Institute, Rovaniemi Research Unit, for the use of the laboratory facilities, and the Academy of Finland and the ARKTIS Graduate School for providing financial support for sample analysis. This research was partially supported by China's National Key Science Program for Global Change Research (No. 2010CB950504), by the European Union Regional Development Foundation, project VeeOBS (3.2.0802.11-0043) and by National Natural Science Foundation of China (NSFC) grant No. 41076125.

\section{REFERENCES}

Barnes I, Hjorth J and Mihalopoulos N (2006) Dimethyl sulfide and dimethyl sulfoxide and their oxidation in the atmosphere. Chem. Rev., 106(3), 940-975 (doi: 10.1021/cr020529)

Bates TS, Calhoun JA and Quinn PK (1992) Variations in the methanesulfonate to sulfate molar ratio in submicrometer marine aerosol particles over the south Pacific Ocean. J. Geophys. Res., 97(D9), 9859-9865 (doi: 10.1029/92JD00411)

Battye W, Aneja VP and Roelle PA (2003) Evaluation and improvement of ammonia emissions inventories. Atmos. Environ., 37(27), 3873-3883 (doi: 10.1016/S1352-2310(03)00343-1)

Bengtsson L, Semenov VA and Johannessen OM (2004) The early twentieth-century warming in the Arctic - a possible mechanism. J. Climate, 17(20), 4045-4057 (doi: 10.1175/15200442(2004)017<4045:TETWIT>2.0.CO;2)

Curran MAJ and 6 others (2002) Post-depositional movement of methanesulphonic acid at Law Dome, Antarctica, and the influence of accumulation rate. Ann. Glaciol., 35, 333-339 (doi: 10.3189/172756402781816528)

Dacey JWH and Wakeham SG (1986) Oceanic dimethylsulfide: production during zooplankton grazing on phytoplankton. Science, 233(4770), 1314-1316 (doi: 10.1126/science.233. 4770.1314)

Davies TD, Vincent CE and Brimblecombe P (1982) Preferential elution of strong acids from a Norwegian ice cap. Nature, 300(5888), 161-163 (doi: 10.1038/300161a0)

Divine DV and Dick C (2006) Historical variability of sea-ice edge position in the Nordic Seas. J. Geophys. Res., 111(C1), C01001 (doi: 10.1029/2004JC002851)
Divine DV and 8 others (2008) Deuterium excess record from a small Arctic ice cap. J. Geophys. Res., 113(D19), D19104 (doi: 10.1029/2008JD010076)

Divine D and 7 others (2011) Thousand years of winter surface air temperature variations in Svalbard and northern Norway reconstructed from ice-core data. Polar Res., 30, 7379 (doi: 10.3402/polar.v30i0.7379)

Döscher A, Gäggeler HW, Schotterer U and Schwikowski M (1996) A historical record of ammonium concentrations from a glacier in the Alps. Geophys. Res. Lett., 23(20), 2741-2744 (doi: 10.1029/96GL02615)

Eichler A, Schwikowski M and Gäggeler HW (2001) Meltwaterinduced relocation of chemical species in Alpine firn. Tellus, 53B(2), 192-203 (doi: 10.1034/j.1600-0889.2001. d01-15.x)

Engelsen O, Hegseth EN, Hop H, Hansen E and Falk-Petersen S (2002) Spatial variability of chlorophyll-a in the Marginal Ice Zone of the Barents Sea, with relations to sea ice and oceanographic conditions. J. Mar. Syst., 35(1-2), 79-97 (doi: 10.1016/S0924-7963(02)00077-5)

Fagerli $H$, Legrand $M$, Preunkert $S$, Vestreng $V$, Simpson $D$ and Cerqueira M (2007) Modeling historical long-term trends of sulfate, ammonium and elemental carbon over Europe: a comparison with ice-core records in the Alps. J. Geophys. Res., 112(D23), D23S13 (doi: 10.1029/2006JD008044)

Fisher DA, Koerner RM, Paterson WSB, Dansgaard W, Gundestrup $\mathrm{N}$ and Reeh N (1983) Effect of wind scouring on climatic records from ice-core oxygen-isotope profiles. Nature, 301(5897), 205-209 (doi: 10.1038/301205a0)

Fisher DA and 12 others (1998) Penny Ice Cap cores, Baffin Island, Canada, and the Wisconsinan Foxe Dome connection: two states of Hudson Bay ice cover. Science, 279(5351), 692-695 (doi: 10.1126/science.279.5351.692)

Fisher JA and 17 others (2011) Sources, distribution, and acidity of sulfate-ammonium aerosol in the Arctic in winter-spring. Atmos. Environ., 454(39), 7301-7318 (doi: 10.1016/ j.atmosenv.2011.08.030)

Fuhrer K, Neftel A, Anklin M, Staffelbach T and Legrand M (1996) High-resolution ammonium ice-core record covering a complete glacial-interglacial cycle. J. Geophys. Res., 101(D2), 4147-4164 (doi: 10.1029/95JD02903)

Goto-Azuma K and Koerner RM (2001) Ice-core studies of anthropogenic sulfate and nitrate trends in the Arctic. J. Geophys. Res., 106(D5), 4959-4969 (doi: 10.1029/ 2000JD900635)

Goto-Azuma K and 6 others (1995) An ice-core chemistry record from Snøfjellafonna, northwestern Spitsbergen. Ann. Glaciol., 21, 213-218

Grinsted A, Moore JC and Jevrejeva S (2004) Application of the cross wavelet transform and wavelet coherence in geophysical time series. Nonlinear Process. Geophys., 11(5-6), 561-566 (doi: 10.5194/npg-11-561-2004)

Grinsted A, Moore JC, Pohjola V, Martma T and Isaksson E (2006) Svalbard summer melting, continentality and sea-ice extent from the Lomonosovfonna ice core. J. Geophys. Res., 111(D7), D07110 (doi: 10.1029/2005JD006494)

Groves DG and Francis JA (2002) Variability of the Arctic atmospheric moisture budget from TOVS satellite data. J. Geophys. Res., 107(D24), 4785 (doi: 10.1029/2002JD002285)

Grumet NS, Wake CP, Zielinski GA, Fisher D, Koerner R and Jacobs JD (1998) Preservation of glaciochemical time-series in snow and ice from the Penny Ice Cap, Baffin Island. Geophys. Res. Lett., 25(3), 357-360 (doi: 10.1029/97GL03787)

Hou S and Qin D (2002) The effect of post-depositional process on the chemical profiles of snow pits in the percolation zone. Cold Reg. Sci. Technol., 34(2), 111-116 (doi: 10.1016/S0165232X(01)00065-9)

Hou S, Qin D, Zhang D, Kang S, Mayewski PA and Wake CP (2003) A 154 a high-resolution ammonium record from the Rongbuk Glacier, north slope of Mt Qomolangma (Everest), Tibet-Himal 
region. Atmos. Environ., 37(5), 721-729 (doi: 10.1016/S13522310(02)00582-4)

Hynes AJ, Wine PH and Semmes DH (1986) Kinetics and mechanism of hydroxyl reactions with organic sulfides. J. Phys. Chem., 90(17), 4148-4156

lizuka $\mathrm{Y}$, Igarashi M, Kamiyama K, Motoyama $\mathrm{H}$ and Watanabe $\mathrm{O}$ (2002) Ratios of $\mathrm{Mg}^{2+} / \mathrm{Na}^{+}$in snowpack and an ice core at Austfonna ice cap, Svalbard, as an indicator of seasonal melting. J. Glaciol., 48(162), 452-460 (doi: 10.3189/ 172756502781831304)

Isaksson E and 10 others (2005a) Two ice-core ${ }^{18} \mathrm{O}$ records from Svalbard illustrating climate and sea-ice variability over the last 400 years. Holocene, 15(4), 501-509 (doi: 10.1191/ 0959683605hl820rp)

Isaksson E, Kekonen T, Moore J and Mulvaney R (2005b) The methanesulphonic acid (MSA) record in a Svalbard ice core. Ann. Glaciol., 42, 345-351 (doi: 10.3189/ 172756405781812637)

Iversen T and Joranger E (1985) Arctic air pollution and large scale atmospheric flows. Atmos. Environ., 19(12), 2099-2108 (doi: 10.1016/0004-6981(85)90117-9)

Jickells TD and 7 others (2003) Isotopic evidence for a marine ammonia source. Geophys. Res. Lett., 30(7), 1374 (doi: 10.1029/2002GL016728)

Johnson MT and 9 others (2008) Field observations of the oceanatmosphere exchange of ammonia: fundamental importance of temperature as revealed by a comparison of high and low latitudes. Global Biogeochem. Cycles, 22(GB1), GB1019 (doi: 10.1029/2007GB003039)

Kameda T, Takahashi S, Goto-Azuma K, Kohshima S, Watanabe O and Hagen JO (1993) First report of ice core analyses and borehole temperatures on the highest icefield on western Spitsbergen in 1992. Bull. Glacier Res., 11, 51-61

Keene WC, Pszenny AAP, Galloway JN and Hawley ME (1986) Seasalt corrections and interpretation of constituent ratios in marine precipitation. J. Geophys. Res., 91(D6), 6647-6658 (doi: 10.1029/JD091iD06p06647)

Kekonen T, Moore JC, Mulvaney R, Isaksson E, Pohjola V and Van de Wal RSW (2002) An 800 year record of nitrate from the Lomonosovfonna ice core, Svalbard. Ann. Glaciol., 35, 261265 (doi: 10.3189/172756402781817121)

Kekonen T, Perämäki P and Moore JC (2004) Comparison of analytical results for chloride, sulfate and nitrate obtained from adjacent ice core samples by two ion chromatographic methods. J. Environ. Monitor., 6(2), 147-152 (doi: 10.1039/B306621E)

Kekonen T and 6 others (2005) The 800 year long ion record from the Lomonosovfonna (Svalbard) ice core. J. Geophys. Res., 110(D7), D07304 (doi: 10.1029/2004JD005223)

Klimenko VV, Klimenko AV and Tereshin AG (2000) Reducing emissions of trace greenhouse gases as an alternative to reducing emissions of carbon dioxide: part II. Therm. Eng., 47(6), 476-483

Koenigk T, Mikolajewicz U, Jungclaus JH and Kroll A (2009) Sea ice in the Barents Sea: seasonal to interannual variability and climate feedbacks in a global coupled model. Climate Dyn., 32(7-8), 1119-1138 (doi: 10.1007/s00382-008-0450-2)

Koerner RM (1979) Accumulation, ablation and oxygen isotope variations on the Queen Elizabeth Islands ice caps, Canada. J. Glaciol., 22(86), 25-41

Kreutz KJ, Mayewski PA, Whitlow SI and Twickler MS (1998) Limited migration of soluble ionic species in a Siple Dome, Antarctica, ice core. Ann. Glaciol., 27, 371-377

Kvingedal B (2005) Sea ice extent and variability in the Nordic Seas 1967-2002. In Drange H, Dokken T, Furevik T, Gerdes R and Berger W eds. The Nordic seas: an integrated perspective. (Geophysical Monograph Series 158) American Geophysical Union, Washington, DC, 38-49

Lefauconnier B, Hagen JO and Rudant JP (1994) Flow speed and calving rate of Kongsbreen glacier, Svalbard, using SPOT images. Polar Res., 13(1), 59-65 (doi: 10.1111/j.1751-8369.1994. tb00437.x)
Legrand $M$ and 6 others (1997) Sulfur-containing species (methanesulfonate and $\mathrm{SO}_{4}$ ) over the last climatic cycle in the Greenland Ice Core Project (central Greenland) ice core. J. Geophys. Res., 102(C12), 26 663-26679 (doi: 10.1029/97JC01436)

Matoba S, Narita H, Motoyama H, Kamiyama K and Watanabe O (2002) Ice core chemistry of Vestfonna Ice Cap in Svalbard, Norway. J. Geophys. Res., 107(D23), 4721 (doi: 10.1029/ 2002JD002205)

Mayewski PA and 7 others (1993) Ice-core sulfate from three Northern Hemisphere sites: source and temperature forcing implications. Atmos. Environ., 27(17-18), 2915-2919

Moore JC and Grinsted A (2009) Ion fractionation and percolation in ice cores with seasonal melting. In Hondoh T ed. Physics of ice core records II. (Supplement Issue of Low Temperature Science 68) Hokkaido University Press, Sapporo, 381-386

Moore JC, Grinsted A, Kekonen T and Pohjola V (2005) Separation of melting and environmental signals in an ice core with seasonal melt. Geophys. Res. Lett., 32(10), L10501 (doi: 10.1029/2005GL023039)

Moore JC, Kekonen T, Grinsted A and Isaksson E (2006) Sulfate source inventories from a Svalbard ice-core record spanning the Industrial Revolution. J. Geophys. Res., 111(D15), D15307 (doi: 10.1029/2005JD006453)

Moore JC and 6 others (2012) Statistical extraction of volcanic sulphate from nonpolar ice cores. J. Geophys. Res., 117(D3), D03306 (doi: 10.1029/2011JD016592)

Morison J, Aagaard K and Steele M (2000) Recent environmental changes in the Arctic: a review. Arctic, 53(4), 359-371

Mulvaney R, Pasteur EC, Peel DA, Saltzman ES and Whung PY (1992) The ratio of MSA to non-sea-salt sulphate in Antarctic Peninsula ice cores. Tellus, 44B(4), 295-303 (doi: 10.1034/ j.1600-0889.1992.t01-2-00007.x)

Nye JF (1963) Correction factor for accumulation measured by the thickness of the annual layers in an ice sheet. J. Glaciol., 4(36), 785-788

O'Dwyer J and 7 others (2000) Methanesulfonic acid in a Svalbard ice core as an indicator of ocean climate. Geophys. Res. Lett., 27(8), 1159-1162 (doi: 10.1029/1999GL011106)

Overpeck J and 17 others (1997) Arctic environmental change of the last four centuries. Science, 278(5341), 1251-1256 (doi: 10.1126/science.278.5341.1251)

Pasteur EC and Mulvaney R (2000) Migration of methane sulphonate in Antarctic firn and ice. J. Geophys. Res., 105(D9), 11 525-11534 (doi: 10.1029/2000JD900006)

Pinglot J-F and 6 others (1999) Accumulation in Svalbard glaciers deduced from ice cores with nuclear tests and Chernobyl reference layers. Polar Res., 18(2), 315-321 (doi: 10.1111/ j.1751-8369.1999.tb00309.x)

Pohjola V and 7 others (2002a) Effect of periodic melting on geochemical and isotopic signals in an ice core on Lomonosovfonna, Svalbard. J. Geophys. Res., 107(D4), 4036 (doi: 10.1029/2000JD000149)

Pohjola VA and 6 others (2002b) Reconstruction of three centuries of annual accumulation rates based on the record of stable isotopes of water from Lomonosovfonna, Svalbard. Ann. Glaciol., 35, 57-62 (doi: 10.3189/172756402781816753)

Read KA and 10 others (2008) DMS and MSA measurements in the Antarctic Boundary Layer: impact of $\mathrm{BrO}$ on MSA production. Atmos. Chem. Phys., 8(11), 2985-2997 (doi: 10.5194/acp-82985-2008)

Ruggirello RM and 8 others (2010) Current use and legacy pesticide deposition to ice caps on Svalbard, Norway. J. Geophys. Res., 115(D18), D18308 (doi: 10.1029/2010JD014005)

Saiz-Lopez A and 6 others (2007) Boundary layer halogens in coastal Antarctica. Science, 317(5836), 348-351 (doi: 10.1126/ science.1141408)

Sakshaug E and Walsh J (2000) Marine biology: biomass, productivity distributions and their variability in the Barents and Bering Seas. In Nuttall M and Callaghan TV eds. The Arctic: environment, people, policy. Harwood Academic, Amsterdam, 161-196 
Samuelsson H (2001) Distribution of melt layers on the ice field Lomonosovfonna, Spitsbergen. (MSc thesis, University of Uppsala)

Seinfeld JH and Pandis SN (1998) Atmospheric chemistry and physics: from air pollution to climate change, John Wiley \& Sons, New York

Sjögren B and 6 others (2007) Determination of firn density in ice cores using image analysis. J. Glaciol., 53(182), 413-419 (doi: 10.3189/002214307783258369)

Solberg S, Schmidbauer N, Semb A, Stordal F and Hov Ø (1996) Boundary-layer ozone depletion as seen in the Norwegian Arctic in spring. J. Atmos. Chem., 23(3), 301-332 (doi: 10.1007/ BF00055158)

Sommer W (2005) Reconstruction of surface temperature variations from temperature measurements along a medium-depth borehole at Holtedahlfonna, Svalbard. (BSc thesis, University of Utrecht)

Spokes LJ, Yeatman SG, Cornell SE and Jickells TD (2000) Nitrogen deposition to the eastern Atlantic Ocean. The importance of southeasterly flow. Tellus B, 52(1), 37-49 (doi: 10.1034/j.16000889.2000.00062.x)

Strass VH and Nöthig EM (1996) Seasonal shifts in ice edge phytoplankton blooms in the Barents Sea related to the water column stability. Polar Biol., 16(6), 409-422

Teinilä K, Hillamo R, Kerminen VM and Beine HJ (2003) Aerosol chemistry during the NICE dark and light campaigns. Atmos. Environ., 37(4), 563-575 (doi: 10.1016/S1352-2310(02)00826-9)

Treffeisen R, Krejci R, Ström J, Engvall AC, Herber A and Thomason $L$ (2007) Humidity observations in the Arctic troposphere over Ny-Ålesund, Svalbard, based on 15 years of radiosonde data. Atmos. Chem. Phys., 7(10), 2721-2732 (doi: 10.5194/acp-72721-2007)
Van de Wal RSW and 6 others (2002) Reconstruction of the historical temperature trend from measurements in a medium-length borehole on the Lomonosovfonna plateau, Svalbard. Ann. Glaciol., 35, 371-378 (doi: 10.3189/172756402781816979)

Van der Wel LG and 8 others (2011) Using high-resolution tritium profiles to quantify the effects of melt on two Spitsbergen ice cores. J. Glaciol., 57(206), 1087-1097 (doi: 10.3189/ 002214311798843368)

Virkkunen K (2004) Snowpit studies in 2001-2002 in Lomonosovfonna, Svalbard. (MSc thesis, University of Oulu)

Virkkunen $\mathrm{K}$ and 6 others (2007) Warm summers and ion concentrations in snow: comparison of present day with Medieval Warm Epoch from snow pits and an ice core from Lomonosovfonna, Svalbard. J. Glaciol., 53(183), 623-634 (doi: 10.3189/002214307784409388)

Watanabe $O$ and 7 others (2001) Studies on climatic and environmental changes during the last few hundred years using ice cores from various sites in Nordaustlandet, Svalbard. Mem. Natl Inst. Polar Res., Spec. Iss. 54, 227-242

Weiler K, Fischer H, Fritzsche D, Ruth U, Wilhelms F and Miller H (2005) Glaciochemical reconnaissance of a new ice core from Severnaya Zemlya, Eurasian Arctic. J. Glaciol., 51(172), 64-74 (doi: 10.3189/172756505781829629)

Whung PY, Saltzman ES, Spencer MJ, Mayewski PA and Gundestrup N (1994) Two-hundred-year record of biogenic sulfur in a south Greenland ice core (20D). J. Geophys. Res., 99(D1), 1147-1156 (doi: 10.1029/93JD02732)

Wu B, Wang J and Walsh J (2004) Possible feedback of winter sea ice in the Greenland and Barents Seas on the local atmosphere. Mon. Weather Rev., 132(7), 1868-1876 (doi: 10.1175/15200493(2004)132<1868:PFOWSI>2.0.CO;2)

MS received 30 October 2012 and accepted in revised form 12 July 2013 